\title{
EFFECTS OF IRRIGATION FREQUENCY AND RETRIEVE CONSUMPTIVE USE ON GROWTH AND PRODUCTION OF SORGHUM UNDER SEMIARID CONDITION
}

\author{
Diman Nafea MuHAmmed and AKRam ABbas KhalaF \\ Soil and Water Science, College of Agricultural Engineering Science, University of Duhok, \\ Kurdistan Region, Iraq
}

(Received: October 26, 2020; Accepted for Publication: December 29, 2020)

\begin{abstract}
The aim of this study to evaluate the effect of drip irrigation frequency and retrieve consumptive use rate on growth parameters of Sorghum crop speed feed variety. The study was carried out at the field of College of Agricultural Engineering Sciences, Duhok University, were studied for growing season (20192020) under conditions of Duhok semi-arid region, using drip irrigation system.

The irrigation frequency $\left(\mathrm{IF}_{1}, \mathbf{I F}_{2}, \mathrm{IF}_{3}\right.$ and $\left.\mathrm{IF}_{4}\right)$ arranged in main plots under three levels of retrieve consumptive use which were $(1.00 \mathrm{CU}, 0.70 \mathrm{CU}$ and $0.40 \mathrm{CU})$ in the sub plots and using 2880 plants density ha ${ }^{-1}$.

The data were recorded on leaf area index, net assimilation rate, growth rate, leaf area, specific leaf area, plant height and crop response factor $(\mathrm{KY})$ were determined.

The results showed that the actual evapotranspiration $\left(\mathbf{E T}_{\mathbf{a}}\right)$ was linearly related with water applied and retrieve consumptive use Under the three levels of retrieve consumptive use $(1.00 \mathrm{CU}, 0.70 \mathrm{CU}, 0.40$ $\mathrm{CU})$ the cumulative actual evapotranspiration $\left(E T_{a}\right)$ were $565.40,395.78$ and $226.16 \mathrm{~mm}$, irrigation water $589.05,419.55$ and $250.13 \mathrm{~mm}$ and water use were $595.68,425.80$ and $256.12 \mathrm{~mm}$. these parameters were measured from the beginning of emergency stage until cutting green forage yield of Sorghum crop.

The values of Sorghum growth parameters of leaf area index, net assimilation rate, relative growth rate, leaf area, specific leaf area, stem radius and total leaves number increased with increasing irrigation frequency, IF and retrieve consumptive use. The highest values of the parameters were obtained for IF1 (once in 1 day) under level (1.00) retrieve consumptive use.

Crop response factor (KY) decreased with increasing irrigation frequency (IF) while it increased with increasing retrieve consumptive use $(\mathrm{CU})$.
\end{abstract}

KEYWORDS: sorghum speed feed variety, growth parameters, irrigation frequency, retrieve consumptive use.

\section{INTRODUCTION}

W ater has been the key limiting factor in most parts of the world for plant growth, Rainfall is not adequate to meet water crop needs (Farahani et al., 2009), with the recent increase in the worlds human population and growing demand for food and water, it has become more important than ever to improve the efficiency of water usage (WUE) for crop production per unit area (Hsiao et al., 2009). In the near future, achieving greater WUE will be the main task and will include the use of techniques and practices that deliver better water to crops (Yihum et al., 2011).

Under drip irrigation, the ponding zone around the emitter is strongly linked to either the level of irrigation or the rate of application of water (Assouline 2002; wang et al., 2006), which thus play a key role in determining the soil water content of the emitter, the amount of water percolation in the root zone and the water absorption pattern (El-Hendawy et al., 2008a, b).

Water stress during stages of tasseling, silking and grain filling was more harmful than water stress during stages of vegetative growth were found by (Musick and Dusik, 1980).

Sorghum is one of the most popular forage crops for summer cultivation in Iraq and is used as a grain forage for animal feeding because of its high protein and carbohydrate content. This crop has the potential for resistant droughts, high temperatures, and development in a wide range of farm soils (Ottman and Olsen, 2009; Prakash et al., 2010).

This crop contributes to increasing the production of green forage during the summer to

akram.khalaf@uod.ac 
meet the requirements of livestock development in Iraq (Al-Mozani and Al- Tai, 2014).

Sorghum crop needs to study some agricultural operations, including the appropriate date of planting, and when to cut or stuff this variety to give the highest yield and good quality, as the date of cultivation affects plant growth due to a change climatic conditions such as temperature and light period from time to time. The changes that occur to climatic conditions that change with the difference in the date of planting may affect most of the vital activities that take place in the soil and plant (Attiya and Whib, 1989).

However, the quality of the forage is affected by the cutting stage and the cutting at the vegetative growth stage gives forage of high nutritional value (Hancoch et al., 2014, Moore and Jung, 2001).

The current study aims to achieve the following objectives:

1. To evaluate the effect of drip irrigation frequency and retrieve consumptive use on growth of Sorghum speed feed variety under semi-arid conditions of Duhok governorate.

2. To determine the amounts of irrigation water applied and water use for irrigation frequency under different levels of retrieve consumptive use of Sorghum.

3. Calculate actual evapotranspiration $\left(\mathrm{ET}_{\mathrm{a}}\right)$ of Sorghum variety under different levels of irrigation frequency and retrieve consumptive use.

4. To determine crop response factor $(\mathrm{KY})$ of Sorghum hybrid under differ level of irrigation frequency and retrieve consumptive use.

5. To select best or optimum combination between irrigation frequency and retrieve consumptive use for Sorghum under study climate.

\section{METHODS AND MATERIALS \\ 1. Experimental site description}

The research was carried out during summer season 2019 at the farm of the department of Field crops, College of Agricultural Engineering Science/ University of Duhok at Semeel site, where latitude, longitude and elevation $36^{\circ}$ $51^{\prime} 42.5^{\prime \prime} \mathrm{N}, 42^{\circ} 51^{\prime} 57.6^{\prime \prime} \mathrm{E}$ and $473 \mathrm{~m}$ above the sea level is approximately $12 \mathrm{~km}$ west of the center of Duhok city / Kurdistan region-Iraq, The area's topography is flat with soil limestone. The area's soil is typical of Vertisols and silty clay texture soil with a content of about $0.9 \%$ organic matter (OM) Figure (1).

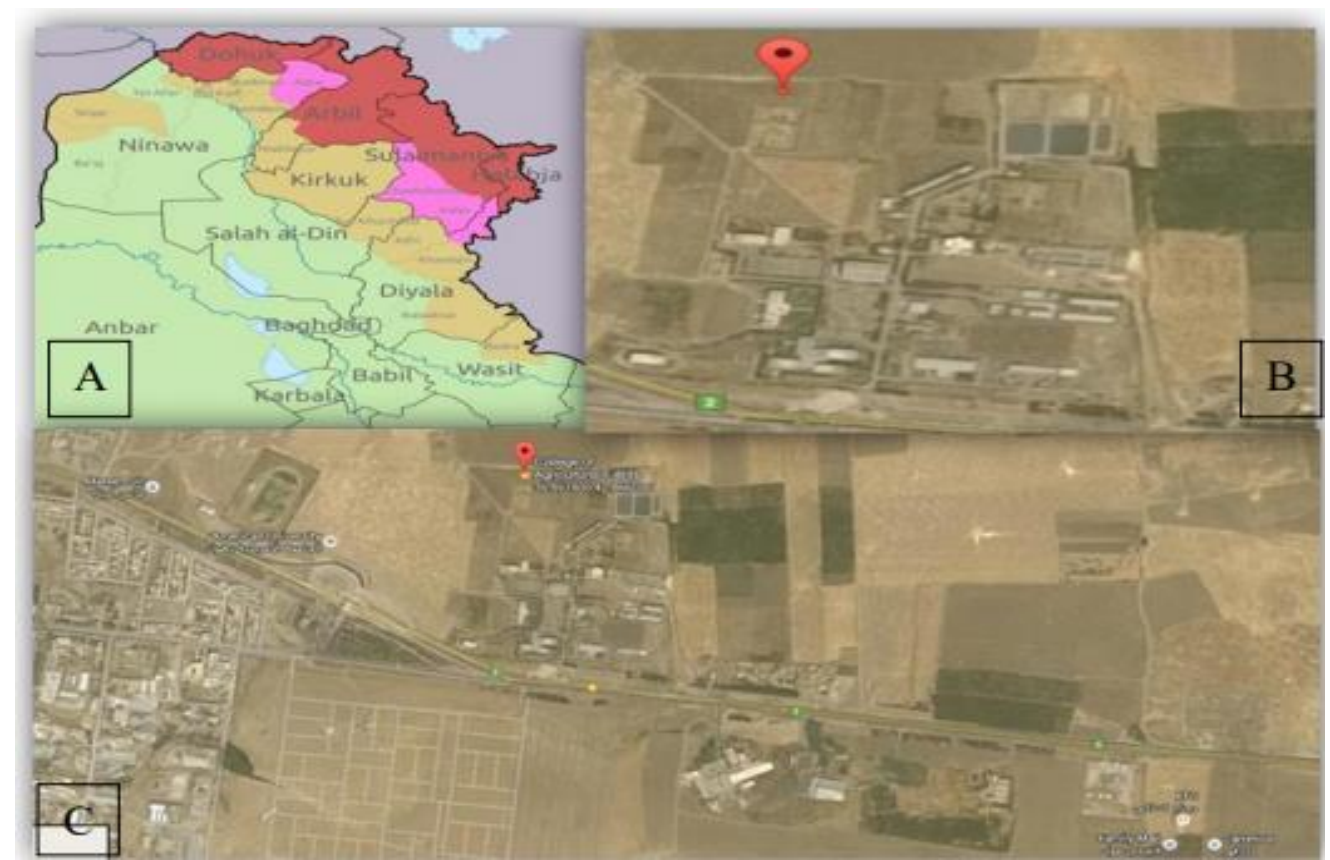

Fig. (1):- The location of experimental site: (A) Duhok Governorate (B) College of Agricultural Engineering Sciences-University of Duhok (C) field of study.

2. Land preparation and soil sampling diman.doski@yahoo.com; akram.khalaf@uod.ac 
the field. Consequently, accordingly, $1.30 \mathrm{~m}$ deep soil pit was dug at the field plots for taking soil samples at 4 soil depths identified including: $0-30,30-60,60-90$, and $90-120 \mathrm{~cm}$, then the samples were taken to laboratory.

Soil samples air-dried, grounded, passed through a $2 \mathrm{~mm}$ sieve thoroughly mixed and continued to be used in plastic bags. In addition, undisturbed soil samples were collected from the above-mentioned depths (using the $4.2 \mathrm{~cm}$ diameter and $5.1 \mathrm{~cm}$ height cylindrical core) to determine the soil bulk density.

\section{Studied elements \\ 3.1. Experimental design}

A split-plot design of two factors with Randomized Complete Block Design (RCBD) with three replications was used. The source of irrigation level was implemented in the main plots, and retrieve consumptive use were implemented in subplots. A layout of experimental plots is shown in Figure (2).

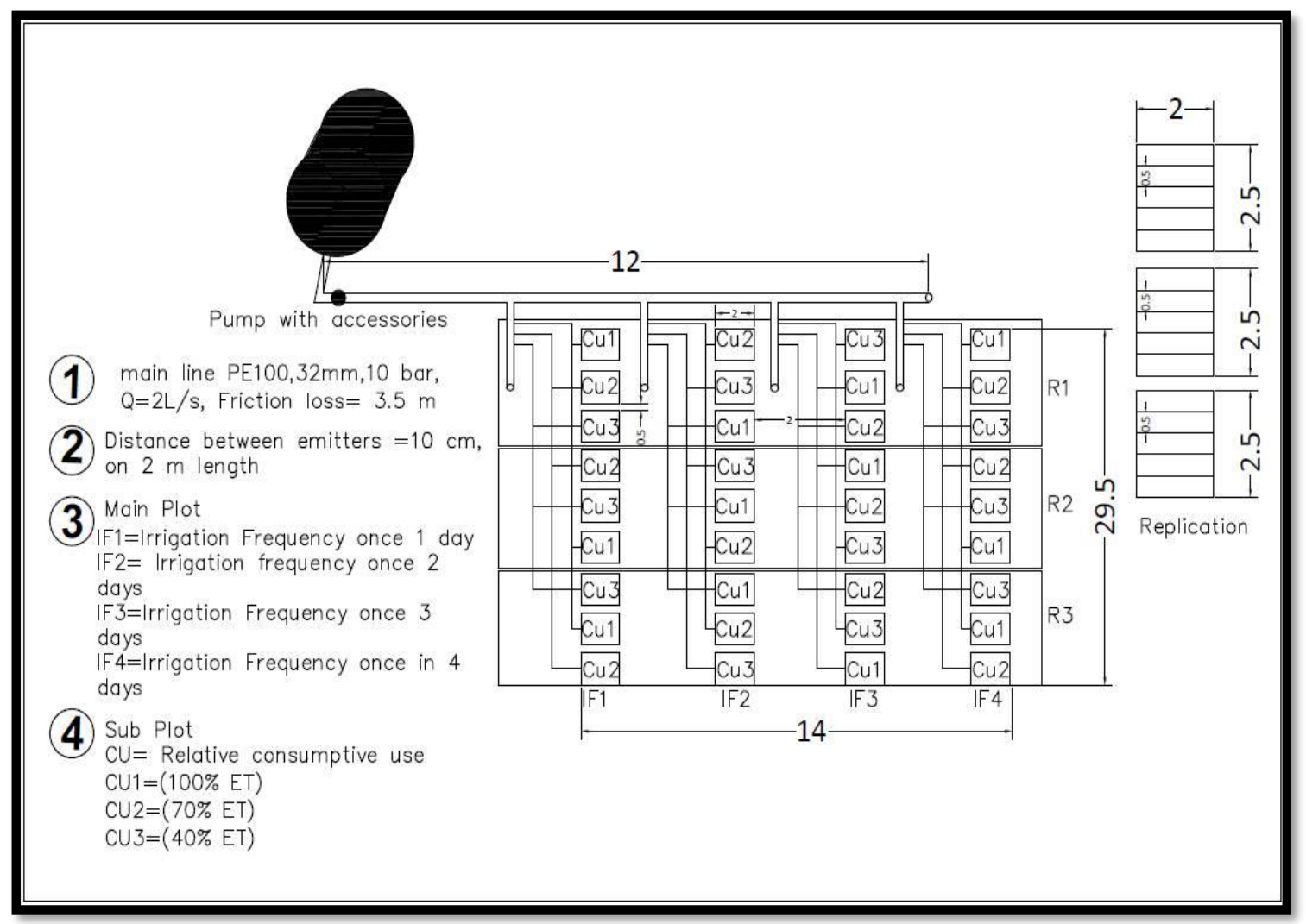

Fig. (2):- Layout of the field experiment at Semeel / University of DuhokCollege of Agricultural engineering sciences

The drip irrigation system is divided into four main sectors, with the irrigation level (once every $1,2,3$, and 4 days) being assigned to the four sectors, Or the main plot were irrigation level which consists of 4 levels, including $I_{1}, I_{2}$, $\mathrm{I}_{3}$ and $\mathrm{I}_{4}$. The retrieve consumptive use: (CU1: 1.00, CU2: 0.70 and CU3:0.40) of the estimated crop evapotranspiration) are randomly nested within each sectors as a subplots, and with each subplot having of same water application rate.

The size of experimental units was $2.5 \mathrm{~m} * 2 \mathrm{~m}$ $\left(5 \mathrm{~m}^{2}\right)$ having 4 rows within each plot with $2.5 \mathrm{~m}$

diman.doski@yahoo.com; in length and $0.5 \mathrm{~m}$ apart, each row consists of 20 plants.

The sowing date was performed in $19^{\text {th }}$ July 2019 by sowing seeds in row at rate of 3 seeds per a pit at $(5-6 \mathrm{~cm})$ depth and then covered with thin layer of soil. Plant thinning was conducted at an early stage of seedling (i.e. at 2-3 true leaves) by keeping one plant per a pit result in a total number of plant populations of 80 plants per plot in order to obtain theoretically optimum plant population of 2880 plants/ ha.

\subsection{Applied irrigation water and water use}

akram.khalaf@uod.ac 
The amounts of irrigation water applied for each irrigation frequency $\mathrm{IF}_{1}, \mathrm{IF}_{2}, \mathrm{IF}_{3}$ and $\mathrm{IF}_{4}$ under three levels of retrieve consumptive use which were ( $1.00 \mathrm{CU}, 0.70 \mathrm{CU}$ and $0.40 \mathrm{CU})$ for growing season (2019-2020) for Sorghum crop speed feed variety.

The amount of irrigation water applied, I, is determined from the calculated water requirement for Sorghum $(\mathrm{mm})$ as determined from the crop coefficient $(\mathrm{Kc})$ and the daily reference evapotranspiration (ETo0 using the following equation (Allen et al., 1998):

$\mathrm{I}=\mathrm{ET}_{\mathrm{o}} * \mathrm{~K}_{\mathrm{c}} \ldots \ldots \ldots \ldots \ldots \ldots \ldots$ (Eq. 1)

Where is:

I= Irrigation water applied $\left(\mathrm{mm} \mathrm{day}^{-1}\right)$.

$\mathrm{ET}_{\mathrm{o}}=$ Reference evapotranspiration $\left(\mathrm{mm} \mathrm{day}^{-1}\right)$.

$\mathrm{K}_{\mathrm{c}}=$ Crop coefficient (dimensionless).

\subsection{Actual crop evapotranspiration (ETa)}

$\mathrm{ET}_{\mathrm{a}}$ was calculated using soil water budget method as Farahani et al. (2009) defined. This can be implemented by calculating all the water balance equation components (Eq.2) for soil profile volume control up to $120 \mathrm{~cm}$ soil layer (root zone depth), as follows:

$\mathrm{ET}_{\mathrm{a}}=\mathrm{P}+\mathrm{I}-\mathrm{D}-\mathrm{R} \pm \Delta \mathrm{S} \ldots \ldots \quad$ (Eq.2)

Where is:

$\mathrm{P}=$ Amount of precipitation $(\mathrm{mm})$.

$\mathrm{I}=$ Irrigation $(\mathrm{mm})$.

$\mathrm{D}=$ Deep percolation below root zone $(\mathrm{mm})$.

$\mathrm{R}=\operatorname{Runoff}(\mathrm{mm})$.

$\Delta S=$ Change in stored water content $(\mathrm{mm})$ of the soil profile.

Since the amount of irrigation was below FC and as a result of using drip IS there was no runoff, the amount of deep percolation and surface runoff was presumed to be negligible or zero.

\subsection{Reference evapotranspiration calculation (ETc)}

The data of rainfall, temperature, relative humidity, solar radiation, sunshine duration and wind speed at $2 \mathrm{~m}$ height were obtained from the center of meteorological station in Duhok city from the period of 1997 to 2019.

Using the Pan evaporation, Blaney-Criddle and Hargreaves -Samani methods, weather data obtained were used to calculate the daily $\mathrm{ET}_{\mathrm{o}}$ $\left(\mathrm{mm} \mathrm{day}{ }^{-1}\right)$ for the local area by using the general $\mathrm{ET}_{\mathrm{c}}$ equation, $\mathrm{ET}_{\mathfrak{c}}$ was calculated as follows:

$$
\mathrm{ET}_{\mathrm{c}}=\mathrm{k}_{\mathrm{c}} * \mathrm{ET}_{\mathrm{o}}
$$

Where is:

$\mathrm{ET}_{\mathrm{c}}=$ Crop evapotranspiration $\left(\mathrm{mm}\right.$ day $\left.^{-1}\right)$.

$\mathrm{K}_{\mathrm{c}}=$ Crop coefficient (dimensionless).

$\mathrm{ET}_{\mathrm{o}}=$ Reference evapotranspiration $\left(\mathrm{mm} \mathrm{day}^{-1}\right)$.

\subsection{Yield response factor}

Yield response factor (KY) used for determining the effect of water stress on crop yield, The relative yield reduction of the relative ET deficit through Ky was determined as shown in the following equation (Doorenbos and Kassam, 1979):

$\mathrm{K}_{\mathrm{y}}=\left[1-\mathrm{Y}_{\mathrm{a}} / \mathrm{Y}_{\mathrm{m}}\right] /\left[1-\mathrm{ET}_{\mathrm{a}} / \mathrm{ET}_{\mathrm{m}}\right] \ldots$ (Eq. 4)

Where:

$\mathrm{Y}_{\mathrm{a}}=$ Actual crop yield $\left(\mathrm{kg} \mathrm{ha}^{-1}\right)$.

$\mathrm{Y}_{\mathrm{m}}=$ Maximum crop yield $\left(\mathrm{kg} \mathrm{ha}^{-1}\right)$.

$\left(1-\mathrm{Y}_{\mathrm{a}} / \mathrm{Y}_{\mathrm{m}}\right)=$ Relative yield decline (dimensionless).

$\left(1-\mathrm{ET}_{\mathrm{a}} / \mathrm{ET}_{\mathrm{m}}\right)=$ Relative evapotranspiration deficit (unit less).

$\mathrm{KY}=$ Yield response factor to water stress (dimensionless).

\subsection{Soil analysis methods \\ 3.6.1. Soil physical analyses}

The soil physical analysis is shown in Table (1), the determination of soil texture using Hydrometer method is described by (Estefan et al., 2013). Soil samples were treated with hydrogen peroxide, and sodium hexameta phosphate was used to physically disperse soil particles. Mechanically, the samples were dispersed with mechanical stirrer. The settling rate of mineral particles in water (Sedimentation technique) has been used to determine the amount of silt-clay particles. Data on retention of soil moisture were calculated by using the pressure plate apparatus method described by (Klute ,1986), After applying different levels of pressure $(-33,-100,-500,-1000$ and $-1500 \mathrm{kPa})$ to remove water from saturated soil slices weighed at $105^{\circ} \mathrm{C}$ for 24 hours after drying and wetting to determine the gravimetric content of soil moisture. 
Table (1):- Physical properties of the studied soil:

\begin{tabular}{|c|c|c|c|c|c|}
\hline \multirow[t]{2}{*}{ Soil property } & \multirow{2}{*}{$\begin{array}{l}\text { Measuring } \\
\text { units }\end{array}$} & \multicolumn{4}{|c|}{ Soil depths (cm) } \\
\hline & & $(0-30)$ & $(30-60)$ & $(60-90)$ & $(90-120)$ \\
\hline \multirow{3}{*}{$\begin{array}{l}\text { Particle } \\
\text { Distribution } \\
\text { (PSD) }\end{array}$} & Sand $\%$ & 4.47 & 5.23 & 4.49 & 3.78 \\
\hline & Silt\% & 54.21 & 46.81 & 49.68 & 53.48 \\
\hline & Clay $\%$ & 41.3 & 47.97 & 45.83 & 42.75 \\
\hline Soil texture & $\ldots$ & Silty Clay & Silty Clay & Silty Clay & Silty Clay \\
\hline Bulk density & $\mathrm{gm} \mathrm{cm}^{-3}$ & 1.366 & 1.382 & 1.44 & 1.58 \\
\hline $\begin{array}{l}\theta \mathrm{m} \text { at }(\mathrm{F} . \mathrm{C}) \text { is equal } \\
-33 \mathrm{kPa}\end{array}$ & $\mathrm{KPa}$ & 31.62 & 30.07 & 28.32 & 28.89 \\
\hline $\begin{array}{l}\theta m \text { at }(W . P) \\
\text { equal }-1500 \mathrm{kPa}\end{array}$ & & 19.83 & 20.01 & 18.13 & 19.00 \\
\hline
\end{tabular}

\subsubsection{Soil chemical analyses}

The soil chemical analysis is shown in Table (2), soil electrical conductivity was calculated using the model of EC-meter after 1:2 (soil: water) soil suspension was prepared and filtered using Whatman No 42 filter paper. The $\mathrm{pH}$ of the soil was measured with integrated glass electrodes using a pH-meter (Rowell, 2014). Calcium carbonate was calculated using calcimeter process as mentioned by (AlSulaivani, 1993).

Cation exchange capacity was determined following extraction of the soil samples using 1 $\mathrm{M}$ ammonium acetate ( $\mathrm{pH} 7.0)$, and the flamephotometer was used to measure cation (Estefan et al. 2013). Nitrogen available was extracted using 1N KCL and calculated using Kjeldahl method (Bashour and Sayegh, 2007).

Table (2):- Chemical properties of the studied soil:

\begin{tabular}{|c|c|c|c|c|c|c|}
\hline \multirow{2}{*}{\multicolumn{2}{|c|}{ Soil property }} & \multirow{2}{*}{$\begin{array}{c}\text { Measuring } \\
\text { units }\end{array}$} & \multicolumn{4}{|c|}{ Soil depths (cm) } \\
\hline & & & $(0-30)$ & $(30-60)$ & $(60-90)$ & $(90-120)$ \\
\hline \multicolumn{2}{|c|}{ Available N } & $\mathrm{mg} \cdot \mathrm{kg}^{-1}$ & 105.97 & 106.24 & 106.38 & 106.31 \\
\hline \multicolumn{2}{|c|}{ Available $\mathbf{P}$} & $\mathrm{mg} \cdot \mathrm{kg}^{-1}$ & 4.88 & 4.84 & 4.90 & 4.87 \\
\hline \multicolumn{2}{|c|}{$\mathrm{pH}$ at $25^{\circ} \mathrm{C}$ in $(1: 2)$ extract } & $\ldots$. & 7.96 & 8.00 & 7.99 & 7.95 \\
\hline \multicolumn{2}{|c|}{$\mathrm{EC}$ at $25^{\circ} \mathrm{C}$} & dS. $m^{-1}$ & 0.52 & 0.369 & 0.352 & 0.303 \\
\hline \multirow{4}{*}{$\begin{array}{l}\text { Soluble } \\
\text { cations }\end{array}$} & $\mathrm{K}^{+}$ & \multirow{4}{*}{$\mathrm{mmolcL}^{-1}$} & 0.2 & 0.16 & 0.17 & 0.18 \\
\hline & $\mathrm{Ca}^{2+}$ & & 1.65 & 1.65 & 1.67 & 1.69 \\
\hline & $\mathrm{Mg}^{2+}$ & & 1.03 & 1.05 & 1.06 & 1.07 \\
\hline & $\mathrm{Na}^{+}$ & & 0.61 & 0.6 & 0.62 & 0.62 \\
\hline \multirow{3}{*}{$\begin{array}{l}\text { Soluble } \\
\text { anions }\end{array}$} & $\mathrm{Cl}^{-}$ & \multirow{3}{*}{$\mathrm{mmolcL}^{-1}$} & 0.5 & 0.55 & 0.59 & 0.59 \\
\hline & $\mathrm{HCO}_{3}^{-}$ & & 2.32 & 2.3 & 2.34 & 2.34 \\
\hline & $\mathrm{CO}_{3}=$ & & Trace & Trace & Trace & Trace \\
\hline \multicolumn{2}{|l|}{$\mathrm{CaCO}_{3}$} & $\mathrm{~g} \mathrm{~kg}^{-1}$ soil & 217.6 & 216.9 & 217.6 & 217.8 \\
\hline \multicolumn{2}{|c|}{ Active $\mathrm{CaCO}_{3}$} & $\mathrm{~g} \mathrm{~kg}^{-1}$ soil & 109.9 & 111.3 & 110.7 & 110.8 \\
\hline
\end{tabular}

\subsection{Statistical Analysis}

The results have been analyzed statistically, using Excel Software and Stat Graphic Technology Release plus 4.0. Least significant difference was used to compare the 0.05 and 0.01 probability levels of the treatment means.

\section{RESULTS AND DISCUSSION}

\subsection{Applied irrigation water and water use}

Figures (3,4,5 and 6) exhibit same consumed amounts of irrigation water as found in IF1, IF2, IF3 with same levels of retrieve consumptive use and in spite of different irrigation events through growing season, it found same amount of consumed irrigation water at the end of

diman.doski@yahoo.com; growing season which were $(5654.04,3957.83)$ and $(2261.61) \mathrm{m}^{3} \mathrm{ha}^{-1}$.

In every irrigation event the amount of water needed to reach field capacity for each irrigation frequencies is a different amount of water therefore the amount of water needed for irrigation frequency IF1,(once in 1 day) differs than the amounts of applied irrigation water for irrigation frequencies IF2 (once in 2 days), IF3 (once in 3 days) and IF4 (once in 4 days) more there according the required water to reach FC for irrigation frequencies follow the order:

Applied water (IF1) < Applied water (IF1< Applied water (IF3) < Applied water (IF4)

Therefore, the amounts of applied water are differed for IF1 during 44, IF2 during 29, IF3 during 22 and IF4 during 18 irrigation events. 


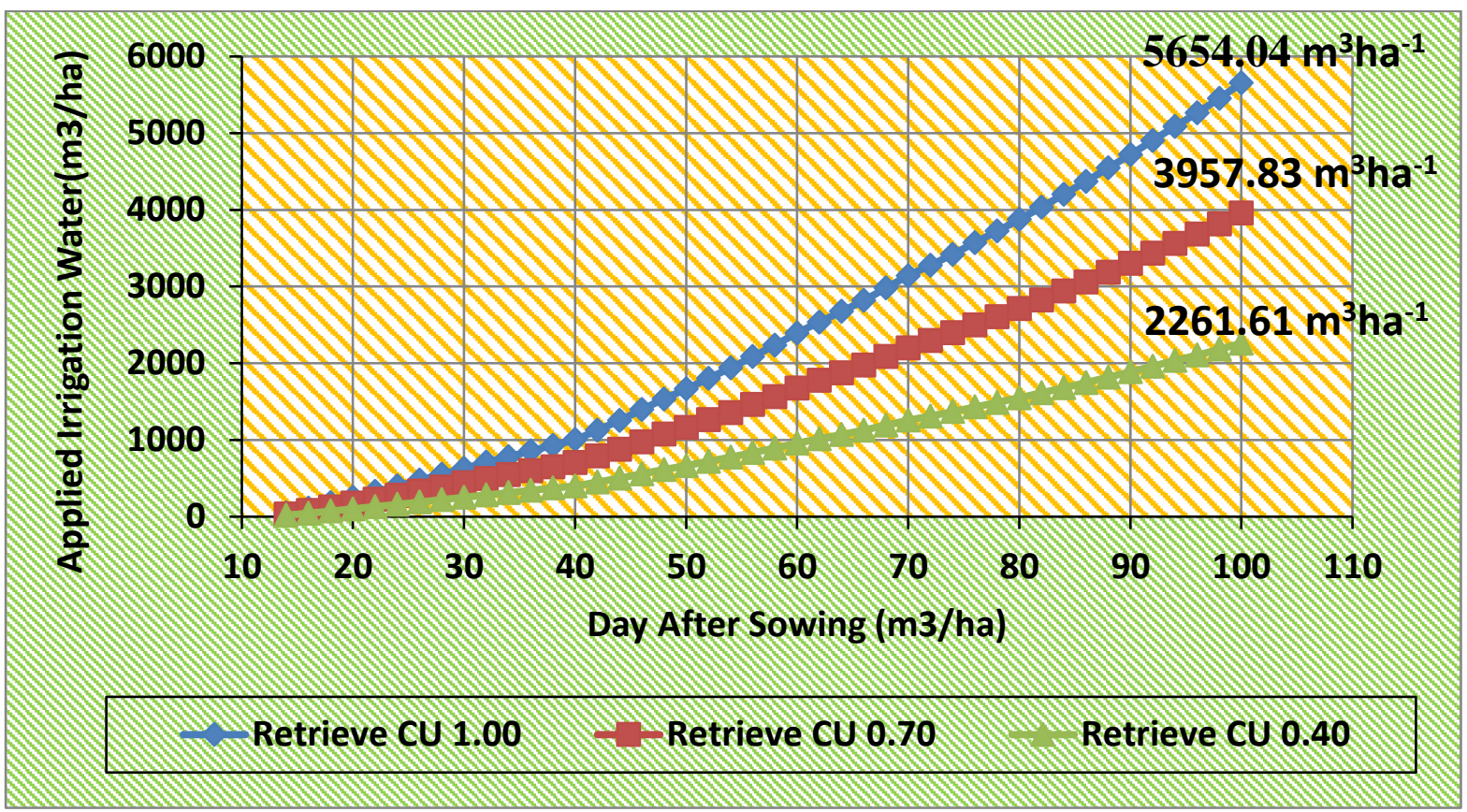

Fig. (3):- Amounts of irrigation water applied for irrigation frequencies IF1 (Once in 1 day) under three consumptive use levels of retrieve through 44 irrigation events.

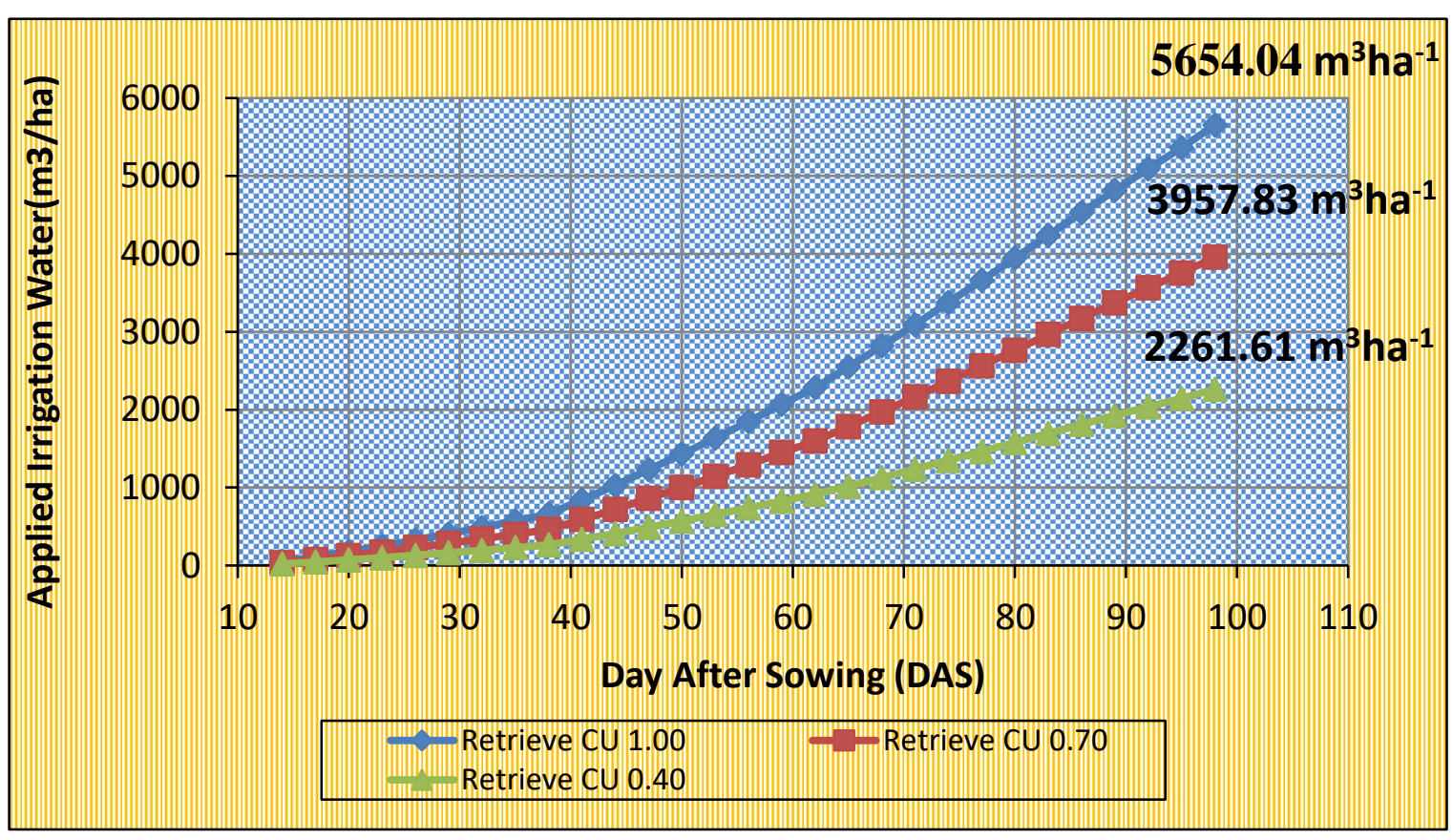

Fig. (4):- Amounts of irrigation water applied for irrigation frequency, IF2 (once in 2 days) under three consumptive use levels of retrieve through 29 irrigation events. 


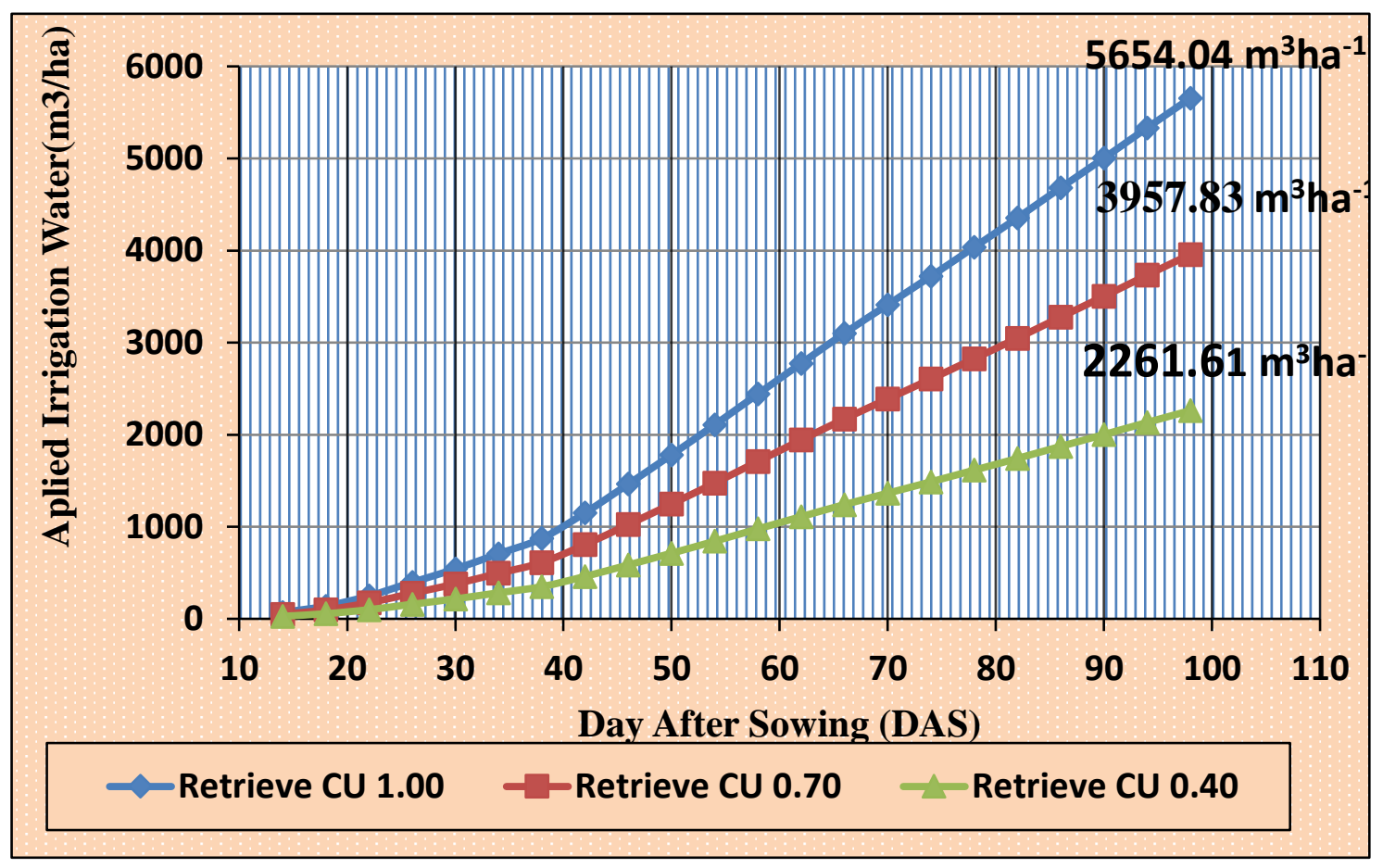

Fig. (5):- Amounts of irrigation water applied for irrigation frequency IF3 (once in 3 days) under three consumptive use levels of retrieve through 22 irrigation events.

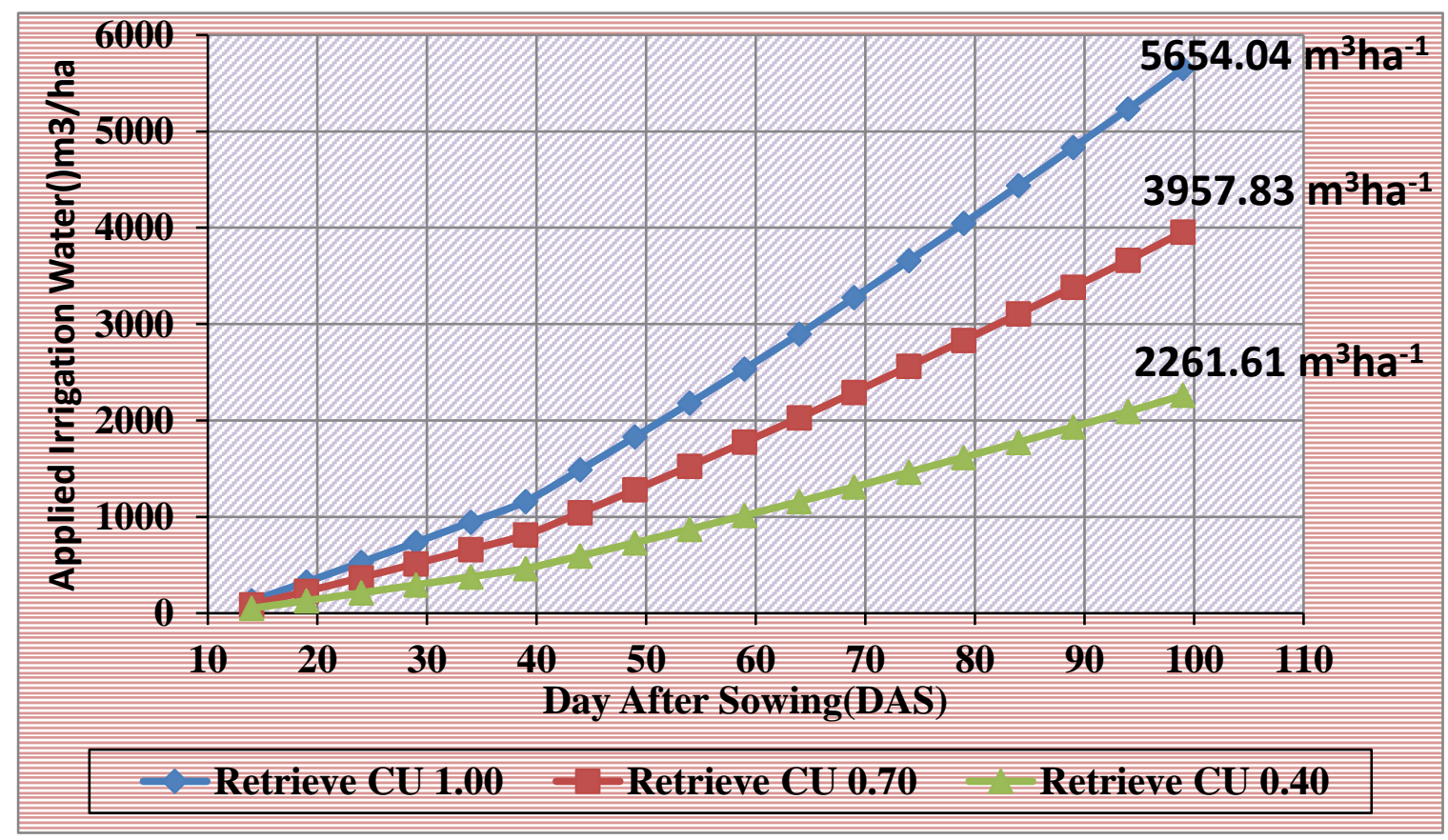

Fig. (6):- Amounts of irrigation water applied for irrigation frequency, IF4 (once in 4 days) under three consumptive use levels of retrieve through 18 irrigation events.

Figures (3, 4, 5 and 6) exhibit same consumed amounts of irrigation water as found in IF1, IF2, IF3 with same levels of retrieve consumptive use and in spite of different irrigation events through growing season.

diman.doski@yahoo.com;

\subsection{Actual crop evapotranspiration (ETa)}

Table (3) presents seasonal crop ET and irrigation water compensation values (Irc). In 2019-2020 season, $\Delta S$ values of all treatments were negative, indicating that the soil became

akram.khalaf@uod.ac 
drier at the end of the growing season. However, $\Delta \mathrm{S}$ values were higher for the IF1 CU1, IF2 CU1, IF3 CU1 and IF4 CU1 treatments under first level of irrigation which is refreshing by total (1.00) consumed water use compared to the remaining treatments of two others levels of consumptive use which are $(0.70$ and 0.40$)$ of water consumptive use and this stats attributed to the scientific fact that at available water the ETa may reach potential evapotranspiration whereas in limit water the Eta decrease or lower than maximum or potential evapotranspiration (Israelson and Hansen, 1980).

Table (3):- Sorghum actual evapotranspiration calculated using the water balance equation I, P, D, $\Delta \mathrm{S}, \mathrm{ET}$ and

\begin{tabular}{|c|c|c|c|c|c|c|c|c|}
\hline Season & $\begin{array}{c}\text { Irrigation } \\
\text { Frequencies }\end{array}$ & $\begin{array}{c}\text { Retrieve } \\
\text { CU }\end{array}$ & $\begin{array}{c}\mathrm{I} \\
(\mathrm{mm})\end{array}$ & $\begin{array}{c}\mathrm{P} \\
(\mathrm{mm})\end{array}$ & $\begin{array}{c}\mathrm{D} \\
(\mathrm{mm})\end{array}$ & $\begin{array}{c}\Delta \mathrm{S} \\
(\mathrm{mm})\end{array}$ & $\begin{array}{l}\mathrm{ETa} \\
(\mathrm{mm})\end{array}$ & $\operatorname{Irc}(\%)$ \\
\hline \multirow{12}{*}{$\begin{array}{l}\text { N } \\
\text { U. } \\
\text { Nิ } \\
\text { N }\end{array}$} & \multirow[t]{3}{*}{$\mathrm{IF}_{1}$ (once in 1 day) } & $1.00 \mathrm{ET}$ & 565.40 & 0 & 0 & -23.3 & 588.7 & 98.45 \\
\hline & & $0.70 \mathrm{ET}$ & 395.78 & 0 & 0 & -20.2 & 405.9 & 95.00 \\
\hline & & $0.40 \mathrm{ET}$ & 226.16 & 0 & 0 & -12.4 & 232.8 & 94.70 \\
\hline & \multirow[t]{3}{*}{$\mathrm{IF}_{2}$ (once in 2 days) } & $1.00 \mathrm{ET}$ & 565.40 & 0 & 0 & -23.1 & 574.1 & 96.00 \\
\hline & & $0.70 \mathrm{ET}$ & 395.78 & 0 & 0 & -15.3 & 401.0 & 96.20 \\
\hline & & $0.40 \mathrm{ET}$ & 226.16 & 0 & 0 & -13.5 & 233.9 & 94.22 \\
\hline & \multirow[t]{3}{*}{$\mathrm{IF}_{3}$ (once in 3 days) } & $1.00 \mathrm{ET}$ & 565.40 & 0 & 0 & -23.0 & 574.0 & 96.00 \\
\hline & & $0.70 \mathrm{ET}$ & 395.78 & 0 & 0 & -21.1 & 406.8 & 94.80 \\
\hline & & $0.40 \mathrm{ET}$ & 226.16 & 0 & 0 & -14.4 & 234.8 & 93.90 \\
\hline & \multirow[t]{3}{*}{$\mathrm{IF}_{4}$ (once in 4 days) } & $1.00 \mathrm{ET}$ & 565.40 & 0 & 0 & -21.9 & 572.9 & 96.20 \\
\hline & & $0.70 \mathrm{ET}$ & 395.78 & 0 & 0 & -12.5 & 398.2 & 96.90 \\
\hline & & $0.40 \mathrm{ET}$ & 226.16 & 0 & 0 & $\begin{array}{l}-8.2 \\
\end{array}$ & 228.6 & 96.40 \\
\hline
\end{tabular}

Heerman (1985) found the amount of ETa depend on the applied irrigation water and change in moisture content of soil at initial and last $( \pm \Delta)$ growing season.

It also found from above table that irrigation water compensation for sorghum crop feed speed variety ranged from $93.9 \%$ for IF3 under CU3 to $96.9 \%$ for IF4 and CU2. The irrigation events was started at the day 18 after sowing and was finished on the $105^{\text {th }}$ DAS depending on the change of the moisture content in the soil profile, which in turn related to the applied water source during irrigation. The first irrigation amount applied for all irrigation

frequencies $\mathrm{IF}_{1}, \mathrm{IF}_{2}, \mathrm{IF}_{3}$ and $\mathrm{IF}_{4}$ were $6.63,6.25$, 5.99 and $6.53 \mathrm{~mm}$ respectively at $40 \mathrm{~cm}$ depth. Final water used reached at 5654.40, 3957.83 and $2261.61 \mathrm{~m}^{3} \mathrm{ha}^{-1}$ under three different levels of retrieve consumptive are approximately equal to soil moisture water consumed at $1.00 \mathrm{CU}, 0.70$ $\mathrm{CU}$ and $0.40 \mathrm{CU}$.

\subsection{Calculated crop evapotranspiration (ETc)}

The results of the monthly (July to October) reference evapotranspiration (ETa), calculated evapotranspiration (ETc) and crop coefficient (kc) for Sorghum (speed feed variety) at Duhok governorate for growing season (2019-2020) are presented in Table

Table (4):- Reference evapotranspiration (ETo) $\mathrm{mm} \mathrm{day}^{-1}$, calculated evapotranspiration (ETc) $\mathrm{mm} \mathrm{day}^{-1}$ and $\mathrm{kc}$ of Sorghum crop for Duhok for growing season (2019-2020).

\begin{tabular}{|c|c|c|c|c|c|c|c|c|}
\hline \multirow[t]{3}{*}{ Periods } & \multirow[t]{3}{*}{ Days } & \multirow[t]{3}{*}{$\mathrm{Kc}$} & \multirow{2}{*}{$\begin{array}{c}\text { Water } \\
\text { balance } \\
\text { Equation }\end{array}$} & \multicolumn{5}{|c|}{ Growing season 2019-2020 } \\
\hline & & & & \multicolumn{2}{|c|}{ Blaney- Criddle } & \multicolumn{2}{|c|}{ Hargreaves } & \multirow{2}{*}{$\begin{array}{c}\text { Average } \\
\mathrm{ET}_{\mathrm{c}} \\
\end{array}$} \\
\hline & & & $\mathrm{ET}_{\mathrm{a}}$ & $\mathrm{ET}_{0}$ & $\mathrm{ET}_{\mathrm{c}}$ & $\mathrm{ET}_{0}$ & $\mathrm{ET}_{\mathrm{c}}$ & \\
\hline 19 Jul. -7 Aug. & 20 & 0.350 & 2.669 & 7.48 & 2.62 & 8.48 & 2.97 & 2.80 \\
\hline 8 Aug. - 6 Sep. & 30 & 0.656 & 4.089 & 6.29 & 4.13 & 7.83 & 5.14 & 4.64 \\
\hline 7 Sep.- 17 Oct. & 40 & 1.030 & 5.851 & 4.44 & 4.57 & 5.58 & 5.75 & 5.16 \\
\hline 18 Oct.-17Nov. & 30 & 0.904 & 5.178 & 2.71 & 2.45 & 3.41 & 3.08 & 2.77 \\
\hline
\end{tabular}

$\mathrm{ET}_{\mathrm{a}}$ was also determined by using water balance method then comparing the results the periods for both ETc and $\mathrm{ET}_{0}$. It was concluded that water requirements for these periods especially for forth (19July to 17 November).
Total ETa for growing season (120 days) was calculated using Blaney Criddle and Hargreaves equations for (2019-2020) (Table 5), $\mathrm{ET}_{\mathrm{a}}$ was also determined by using water balance for same periods. 
Table (5) :-Actual evapotranspiration (ETa), cumulative reference evapotranspiration $\left(\mathrm{ET}_{0}\right), \mathrm{kc}$ and $\mathrm{ks}$ for the growing season (2019-2020) at different levels of retrieve (1.00, 0.70 and 0.40) consumptive use for Duhok governorate.

\begin{tabular}{|c|c|c|c|c|c|c|c|c|c|c|}
\hline \multirow{4}{*}{$\begin{array}{c}\text { Retrieve } \\
\text { consumptive use }\end{array}$} & \multirow[t]{4}{*}{ Days } & water & \multicolumn{8}{|c|}{ Growing season 2019-2020 } \\
\hline & & \multirow{3}{*}{$\frac{\text { Balance }}{\text { Equation }}$} & \multirow{2}{*}{\multicolumn{3}{|c|}{ Blaney- Criddle }} & \multirow{2}{*}{\multicolumn{3}{|c|}{ Hargreaves }} & \multirow{2}{*}{\multicolumn{2}{|c|}{ Average }} \\
\hline & & & & & & & & & & \\
\hline & & & $\mathrm{ET}_{0}$ & Kc ks & Ks & $\mathrm{ET}_{0}$ & kc ks & ks & $\mathrm{Kc}$ & ks \\
\hline$(1.00) \mathrm{CU}$ & 20 & 565.40 & 786 & 0.719 & 1.00 & 748 & 0.756 & 1.00 & 0.74 & 1.00 \\
\hline$(0.70) \mathrm{CU}$ & 30 & 395.78 & 786 & 0.504 & 0.70 & 748 & 0.529 & 0.70 & 0.74 & 0.70 \\
\hline$(0.40) \mathrm{CU}$ & 40 & 226.16 & 786 & 0.288 & 0.40 & 748 & 0.302 & 0.40 & 0.74 & 0.40 \\
\hline
\end{tabular}

Parameters kc and ks then determined by applying following equations:
$\mathrm{ET}_{\mathrm{m}}=\mathrm{kc}^{*} \mathrm{ET}_{0}$
$\mathrm{ET}_{\mathrm{a}}=\mathrm{kc} \mathrm{ks} * \mathrm{ET}_{0}$
Where is:

ks is the soil water availability factor.

\subsection{Relation between Irrigation water use and $\left(\mathbf{E T}_{\mathrm{a}}\right)$}

Amount of irrigation water applied, total irrigation events irrigation water saving, $\mathrm{ET}_{\mathrm{a}}$ and $\mathrm{ET}_{\mathrm{a}} / \mathrm{ET}_{\mathrm{m}}$ ratios exhibited in Table (6).

Table (6):- Total number of irrigation events, irrigation water applied, water use and ETa of Sorghum for three retrieve consumptive use for irrigation frequency, IF1.

\begin{tabular}{|c|c|c|c|c|c|c|c|c|c|}
\hline \multirow{2}{*}{$\begin{array}{c}\text { Retrieve } \\
\text { consumptive } \\
\text { Use }\end{array}$} & \multirow{2}{*}{$\begin{array}{c}\text { No. of } \\
\text { irrigation } \\
\text { events }\end{array}$} & \multirow{2}{*}{$\begin{array}{l}\text { WS } \\
\text { Initial } \\
(\mathrm{mm})\end{array}$} & \multirow{2}{*}{$\begin{array}{l}\text { WS } \\
\text { Last } \\
(\mathrm{mm})\end{array}$} & \multirow[t]{2}{*}{$\begin{array}{c}\Delta \mathrm{S} \\
(\mathrm{mm})\end{array}$} & \multirow[t]{2}{*}{$\begin{array}{l}\text { Irrigation } \\
(\mathrm{mm})\end{array}$} & \multirow{2}{*}{$\begin{array}{l}\mathrm{WU} \\
(\mathrm{mm})\end{array}$} & \multirow{2}{*}{$\begin{array}{c}\text { Irrigation } \\
\text { IWater } \\
\text { saving } \\
(\%)\end{array}$} & \multirow[t]{2}{*}{$\begin{array}{r}\mathrm{ET}_{\mathrm{a}} \\
(\mathrm{mm})\end{array}$} & \multirow[t]{2}{*}{$\mathrm{ET}_{\mathrm{a}} / \mathrm{ET}_{\mathrm{m}}$} \\
\hline & & & & & & & & & \\
\hline$(1.00) \mathrm{CU}$ & 44 & 6.63 & 30.28 & 23.65 & 589.05 & 595.68 & 0.00 & 565.40 & 1.00 \\
\hline$(0.70) \mathrm{CU}$ & 44 & 6.25 & 30.03 & 23.77 & 419.55 & 425.80 & 45.18 & 395.78 & 0.70 \\
\hline$(1.00) \mathrm{CU}$ & 44 & 5.99 & 29.97 & 23.97 & 250.13 & 256.12 & 61.49 & 226.16 & 0.40 \\
\hline
\end{tabular}

Actual evapotranspiration was linearly increased with retrieve consumptive these results are in agreement with finding of (Payero et al., 2008; Fattah, 2009).

Payero et al., (2008) also revealed that $\mathrm{ET}_{\mathrm{a}}$ increased with increase the retrieve consumptive use or applied water to extent the retrieve became excessive then no increase in $\mathrm{ET}_{\mathrm{a}}$.

\subsection{Sorghum studied parameters}

\subsubsection{Growth parameters}

\subsubsection{Leaf Area Index}

The data of Leaf area index (LAI), presented in Figure (7) showed that the effect of $\mathrm{IF}_{1}$ and $\mathrm{IF}_{2}$ reflected on increased LAI of Sorghum when compared with difference was showed significant effect for IF1, IF2 and consistently had higher LAI than IF3 and IF4
It found that LAI was significantly affected by irrigation frequency and retrieve consumptive use and not significant in interaction between irrigation frequencies and retrieve consumptive use.

Maximum LAI value was 3.599 and minimum LAI value was 3.123 due to different irrigation frequencies for sorghum speed feed variety as shown in Figure (7), This research was in line with (Saberi \& Aishah, 2013) that there have been significant differences in irrigation frequency LAI $(\mathrm{P}<0.01)$.

The results of this study are in agreement with (Abdelmula and Sabiel,2007) who states that "The response of hybrids to drought severity and period varies based on their genetic structure and adaptability." 


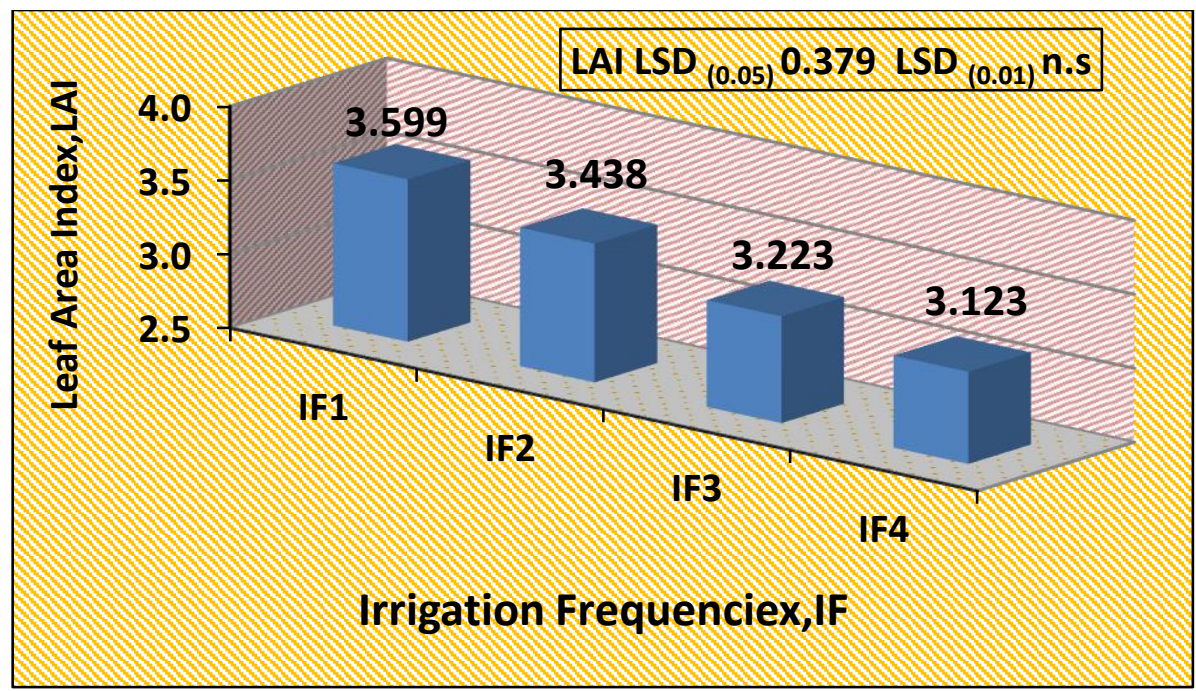

Fig. (7):- Effect of irrigation frequencies on leaf area index of Sorghum speed feed variety.

There is decreasing in LAI by decreasing of retrieve consumptive use from (3.720) to (2.874) at reducing retrieve consumed water from (1.00) $\mathrm{CU}$ to (0.40) CU respectively, for Sorghum speed feed variety as noticed in Figure (8).
The application of good quality irrigation water created more large leaves, resulting in a more photosynthetic region, other research (Fghire et al., 2017).

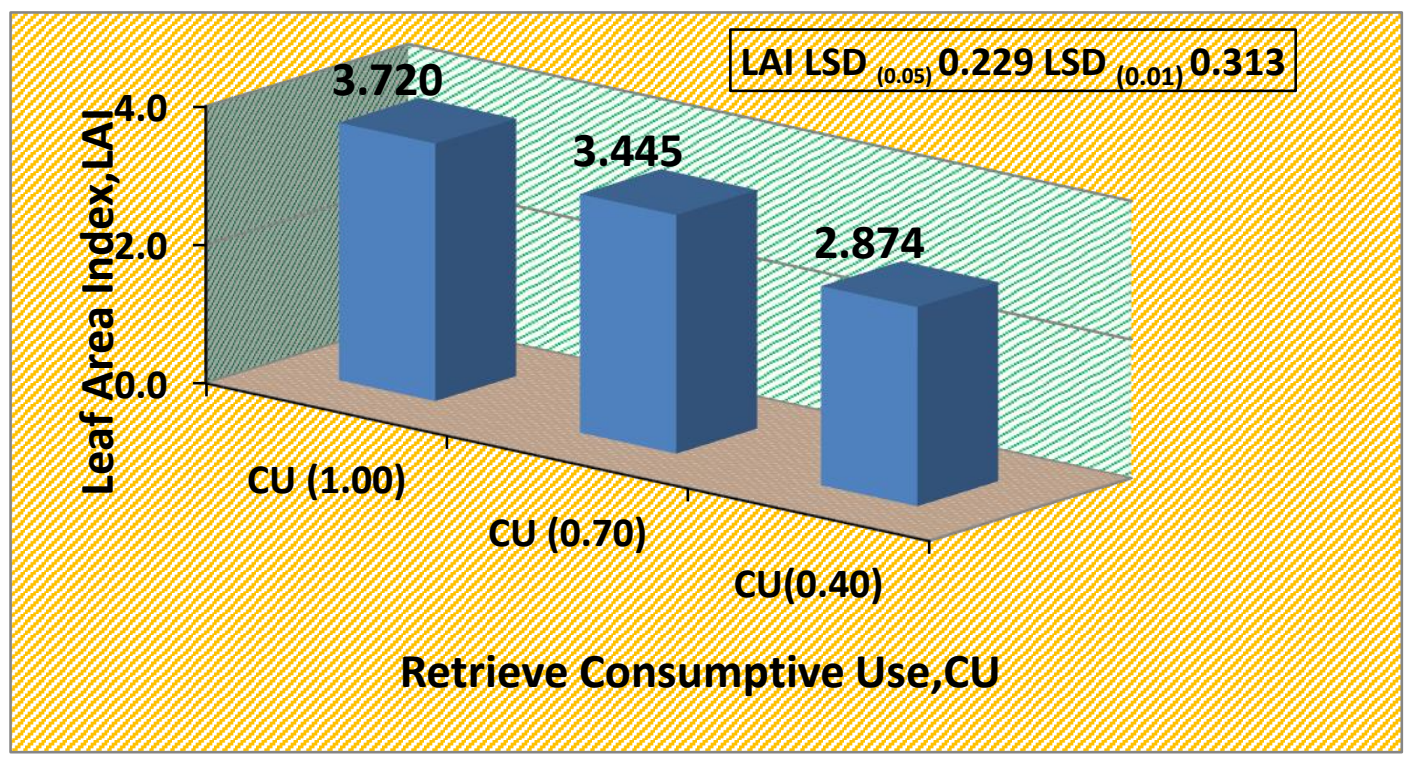

Fi. (8):- Effect of retrieve consumptive use on leaf area index of Sorghum Speed Feed Variety

Higher LAI value was 4.104 obtained by IF $1 *(1.00) \mathrm{CU}$, while the lower LAI value 2.466 was obtained by IF2*(040) CU. In general, there was a similar tendency between TLA and LAI parameters, as shown in Fgure (9).
This finding is consistent with (Pandey et al., 2000), who stated that the highest LAI value for grain maize was obtained under conditions of maximum irrigation (without water stress), water stress creates a decrease in the leaf area index (Jamieson et al., 1995; Stone et al., 2001). 


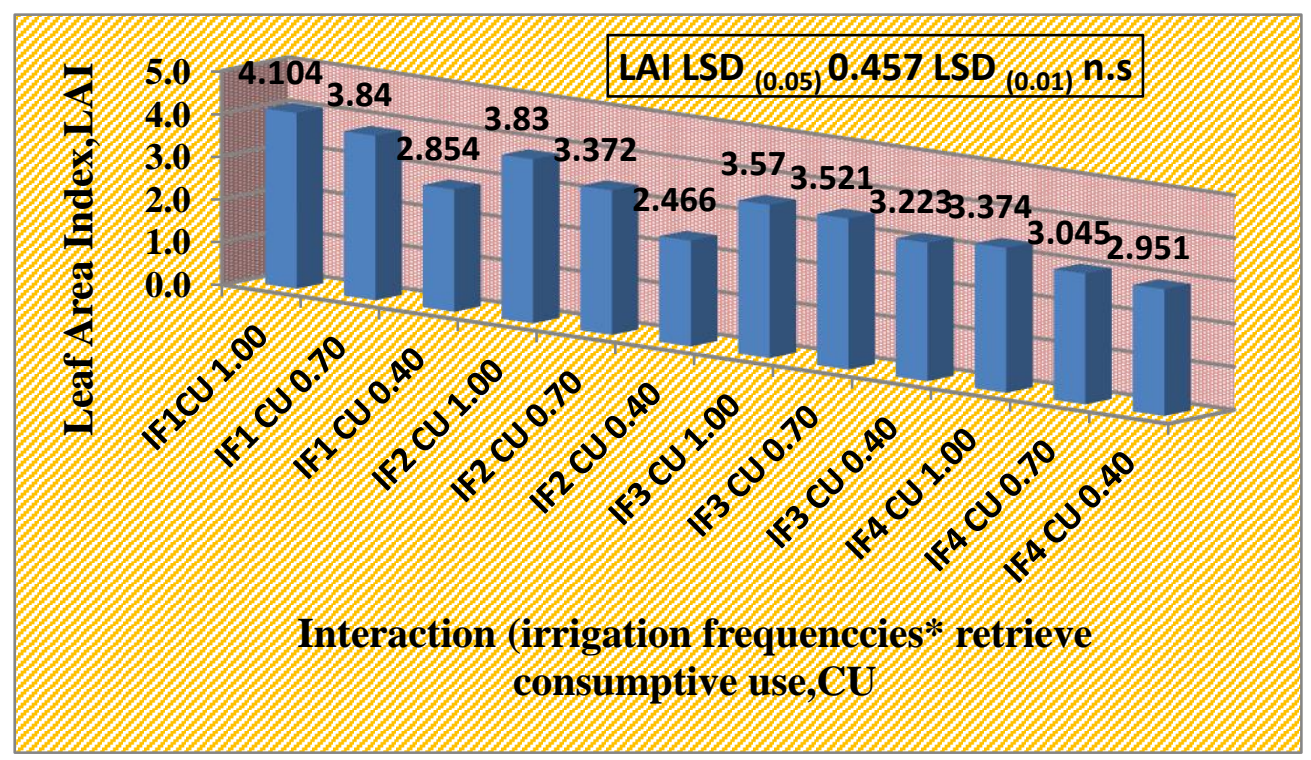

Fig. (9) :-Effect of interaction (irrigation frequencies and retrieve consumptive use on LAI of Sorghum speed feed variety

\subsubsection{Net Assimilation Rate NAR $\left(\mathrm{g} / \mathrm{cm}^{2} / \mathrm{day}\right)$}

Effects of irrigation frequencies, retrieve consumptive use and their interaction on NAR are shown in Figures (10, 11 and 12) there was high significant deference in irrigation frequencies retrieve consumptive use, and there was no significant deference on their interaction.

Irrigation frequency $\mathrm{IF}_{2}$ and, retrieve consumptive use (CU1.00) recorded a higher
NAR than other. The maximum value of NAR $3.925 \mathrm{~g} / \mathrm{cm}^{2} /$ day for IF2 irrigation frequency, while the minimum value of NAR was $2.999 \mathrm{~g} / \mathrm{cm}^{2} /$ day obtained for IF4 irrigation level, The maximum value NAR was $3.981 \mathrm{~g} / \mathrm{cm}^{2} /$ day for(1.00)CU retrieve while the minimum value was $2.986 \mathrm{~g} / \mathrm{cm}^{2} /$ day under level $(0.40) \mathrm{CU}$ retrieve.

Highest NAR of 4.437 was obtained at IF2*(1.00) CU while the lowest NAR was 2.393 was obtained at IF4*(0.40) CU for the retrieved.

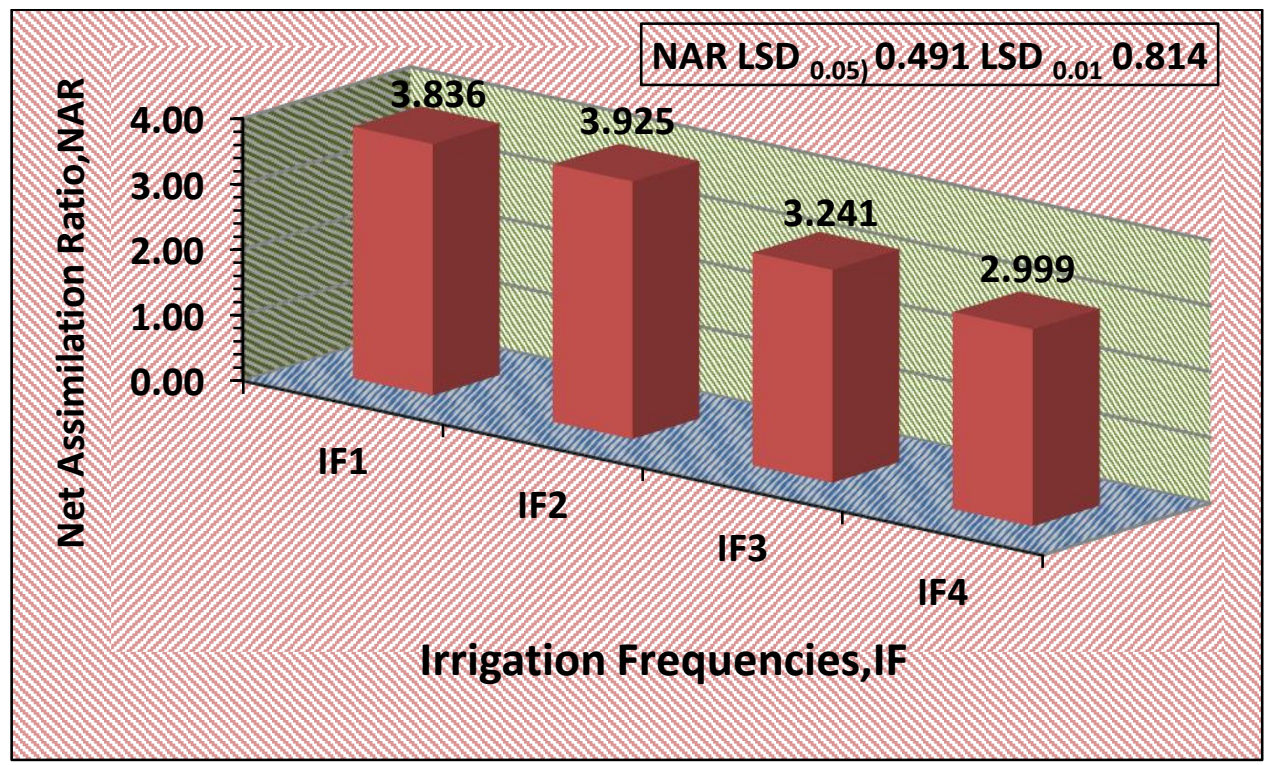

Fig. (10):- Effect of irrigation frequencies on a net assimilation rate of Sorghum speed feed variety 


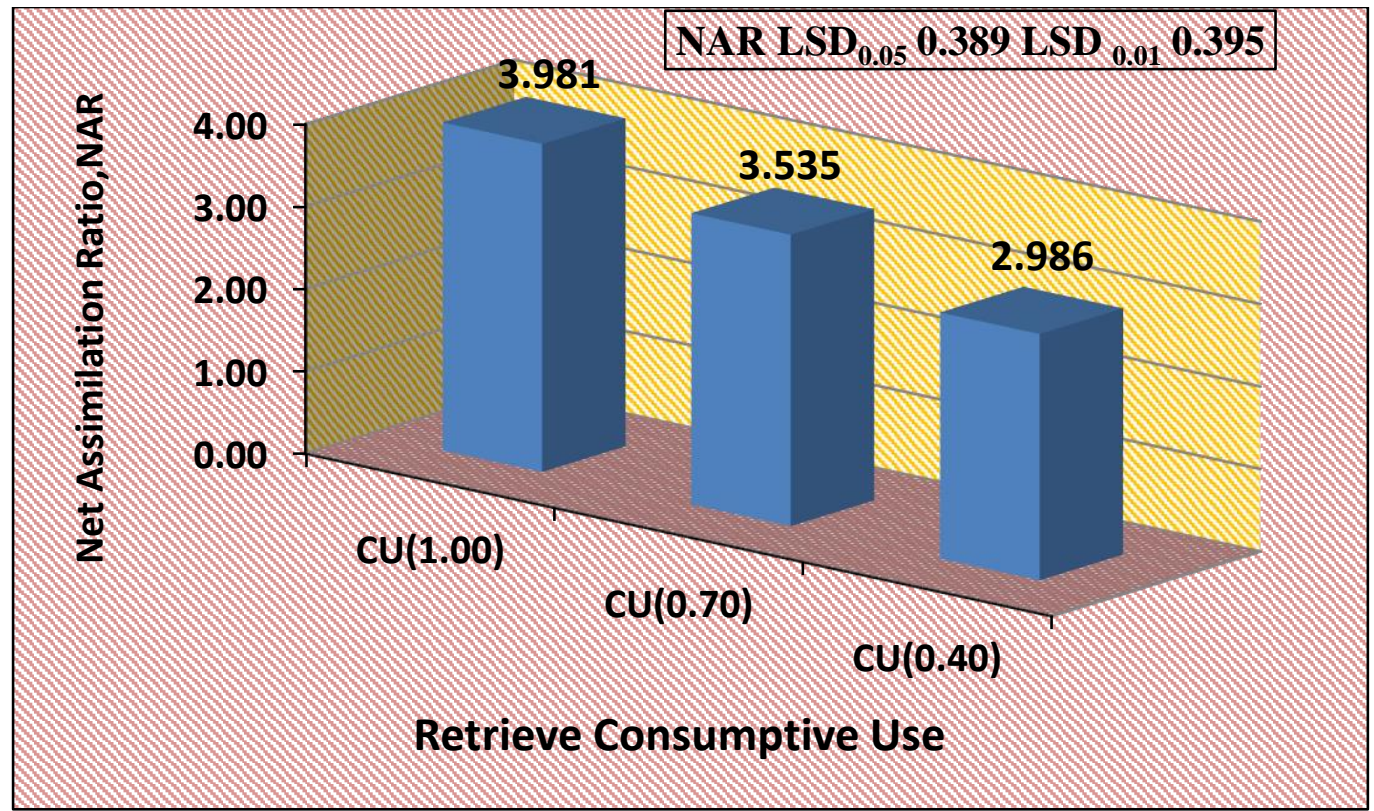

Fig. (11):- Effect of retrieve consumptive use on a net assimilation rate of Sorghum speed feed variety

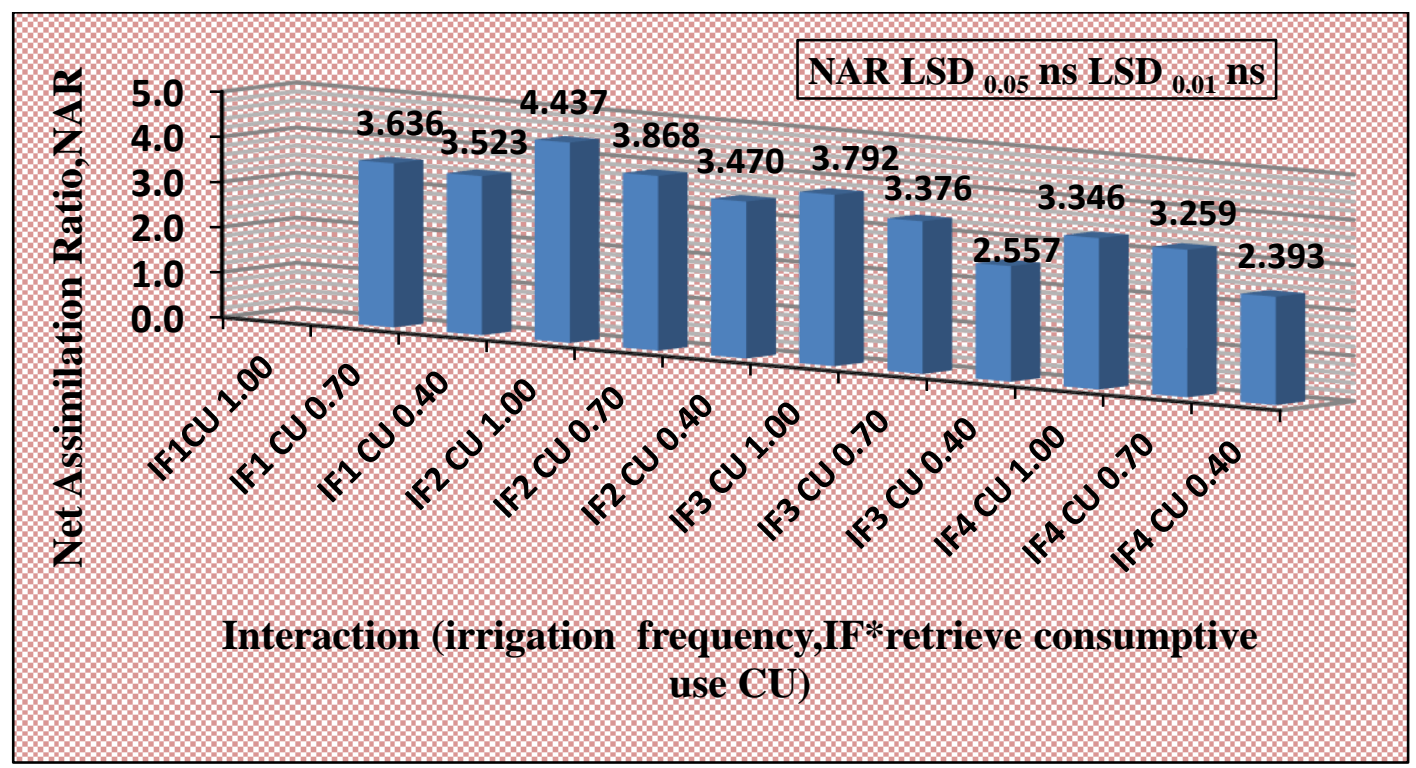

Fig. (12):- Effect of interaction (irrigation frequencies and retrieve consumptive use on net assimilation rate of Sorghum speed feed variety

The results of current research are in agreement with the finding of (Saberi \& Aishah, 2013) there were significant differences $(\mathrm{P} \leq 0.01)$ in NAR irrigation frequencies, Where the NAR value at beginning was low and increased by decreasing irrigation levels (Pollo et al., 2018). In addition, NAR was incompatible with time (Enyi, 1977, Gardner et al., 1991) and affected by LAI.

\subsubsection{Relative Growth Rate (RGR) (g/g/day)}

The statistical analysis shows that there was highly significant difference in the RGR $(\mathrm{P} \leq 0.01)$ of the Sorghum crop irrigation frequencies, retrieve consumptive use, and there was no significant deference on their interaction.

The maximum value of RGR $0.091 \mathrm{~g} / \mathrm{g} / \mathrm{day}$ was obtained for irrigation frequency IF1, while the minimum value $0.067 \mathrm{~g} / \mathrm{g} / \mathrm{day} /$ was found at IF2, Figure (13). 


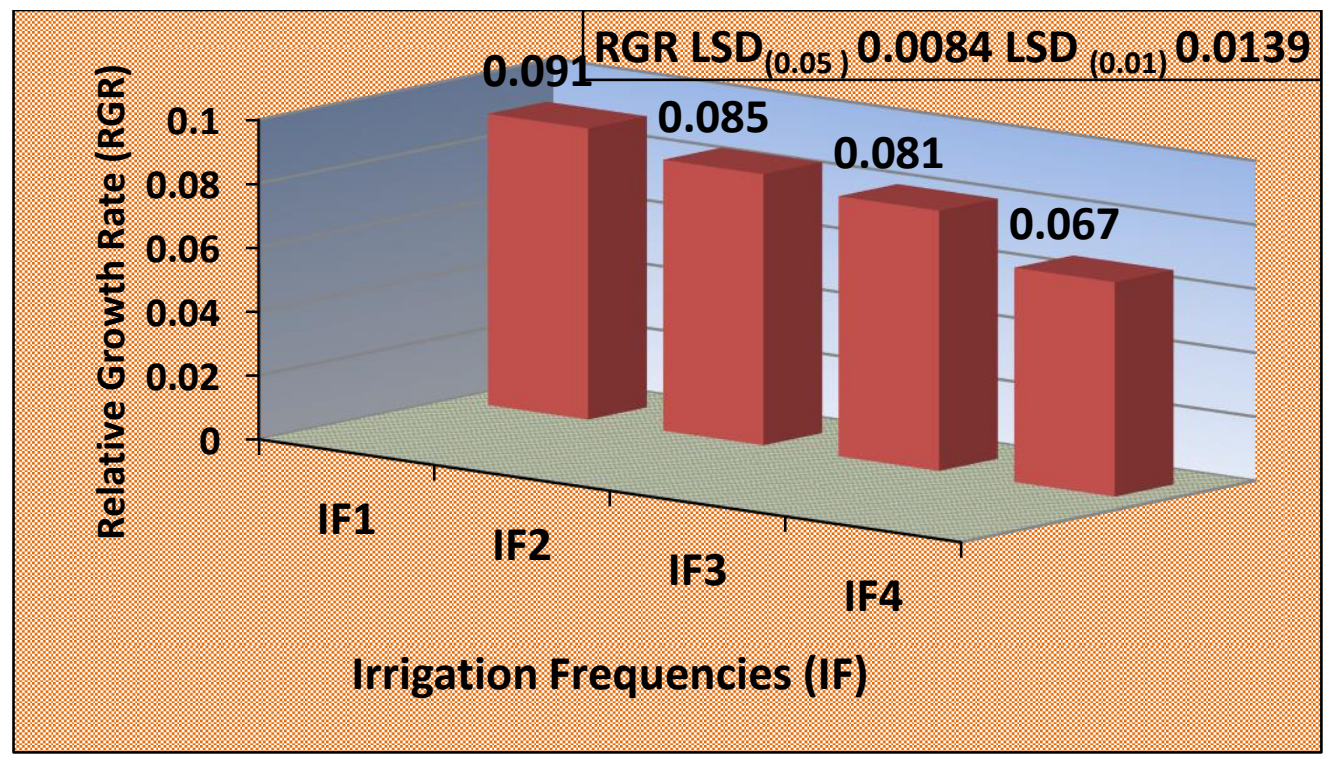

Fig. (13):- Effect of irrigation frequencies on relative growth rate of Sorghum speed feed variety

The maximum value was $0.0895 \mathrm{~g} / \mathrm{g} / \mathrm{day}$ found for total retrieve consumptive while the minimum value was $0.0731 \mathrm{~g} / \mathrm{g} /$ day was given at retrieve 0.40 consumptive use, Figure (14).

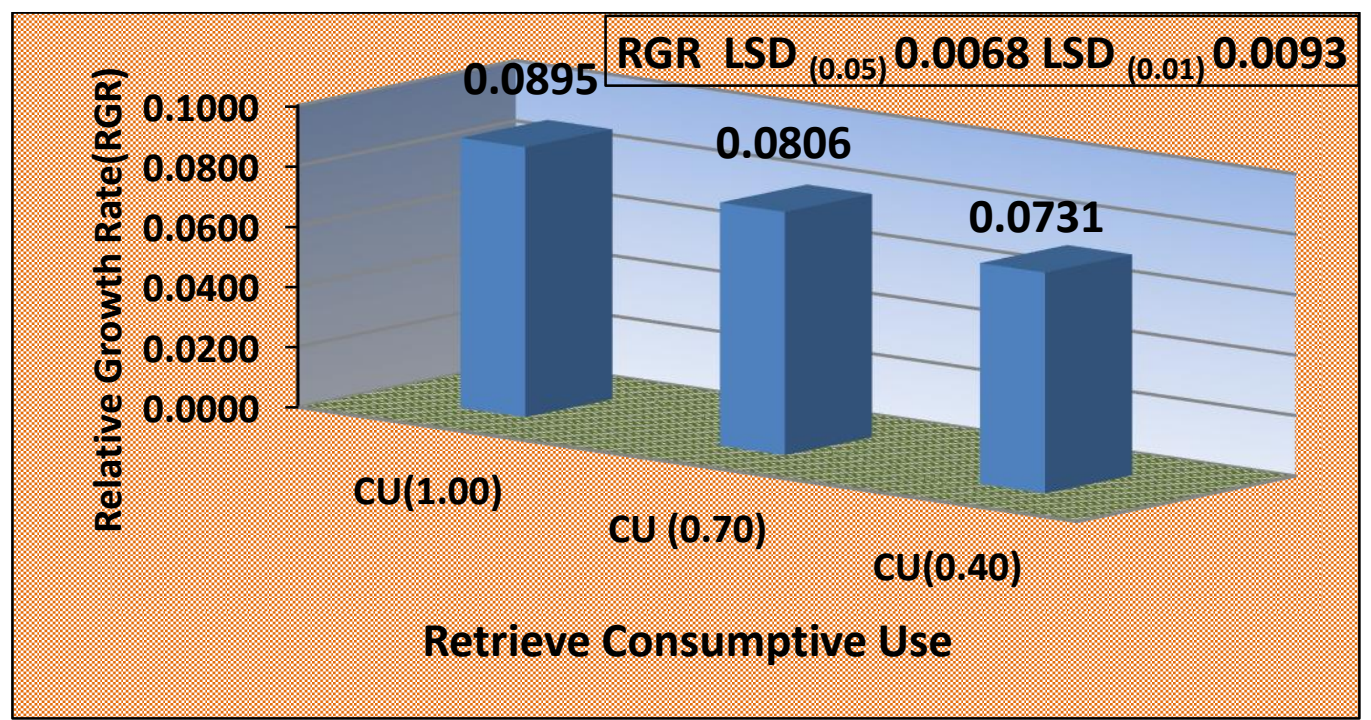

Fig. (14):- Effect of retrieve consumptive on relative growth rate of Sorghum speed feed variety

Highest RGR of 0.099 was obtained at $\mathrm{IF} 1 *(1.00) \mathrm{CU}$ while the lowest RGR was 0.057 was obtained at IF4*(0.40) CU for the retrieved, Figure (15). 


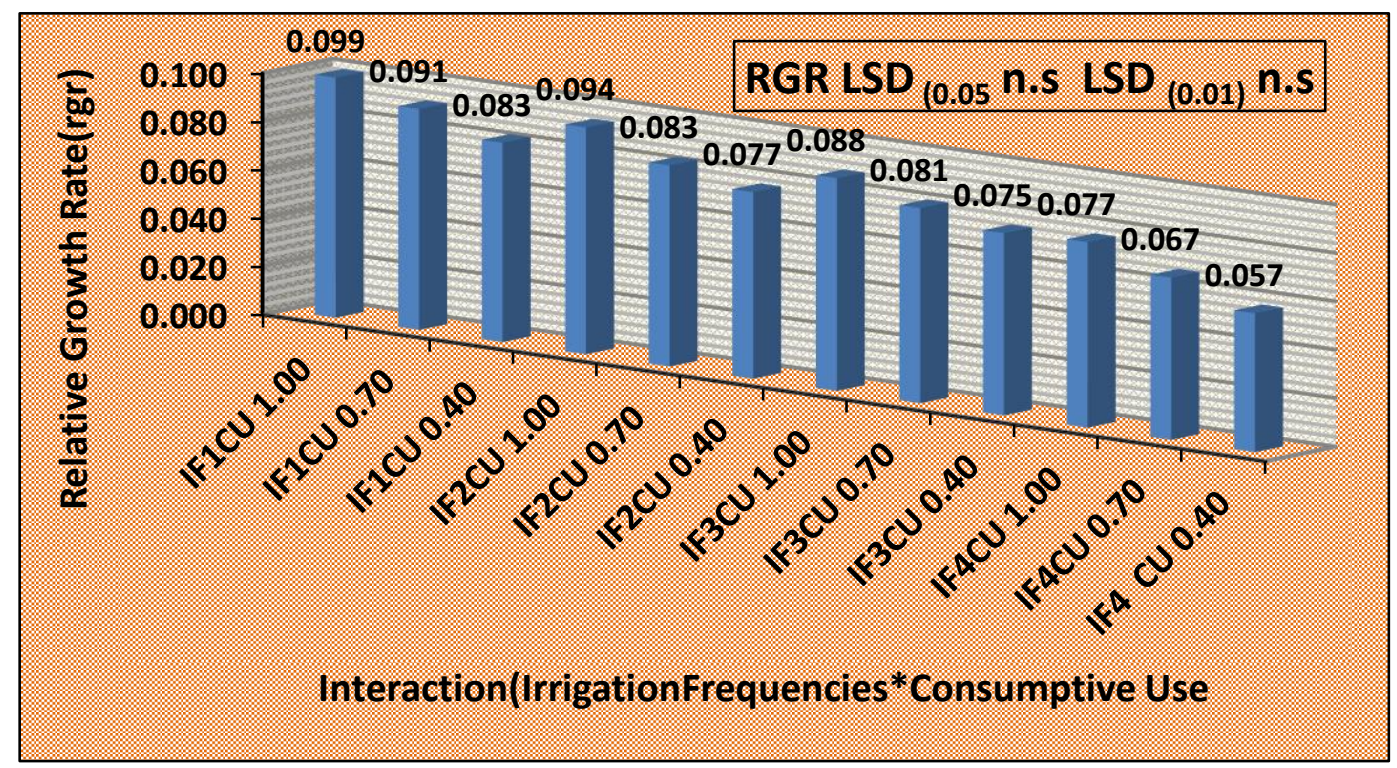

Fig. (15):- Effect of interaction (irrigation frequencies and retrieve consumptive use on relative growth rate of Sorghum speed feed variety

(Ramazanzadeh and Asgharipur, 2011) who stated that RGR tends to be low on initial growth due to imperfect land cover resulting in low light detection.

However, as the leaf area grew and the less light it transmitted through the lower canopy layer, the value of the RGR increased rapidly and was the maximum at the flowering / blooming level. The same view was expressed by (Addo-Quaye et al., 2011), who claimed that RGR had a linear relationship with LAI, where the higher perceived light will have a higher LAI and RGR value, and vice versa.

\subsubsection{Leaf area (LA)}

Leaf area (LA) was significantly affected (P $\leq 0.01)$ by irrigation frequencies and retrieve consumptive use as illustrated in Table (7). The effect of irrigation frequencies on leaf area showed that the highest value of LA (254.222 $\left.\mathrm{cm}^{2}\right)$ for IF1 and lowest value of LA (180.333 $\mathrm{cm}^{2}$ ) was observed in IF4. LA was also significantly affected by retrieve consumptive use. (1.00) $\mathrm{CU}$ had a higher LA which was $233.418 \mathrm{~cm}^{2}$ and the lower value $195.583 \mathrm{~cm}^{2}$. The interaction between IF and retrieve $\mathrm{CU}$ on LA was not significant. Higher LA value was obtained by IF1* (1.00) CU, while the lower LA was obtained by IF4* (0.40) CU.

Table (7) :-Leaf area (LA) affected by irrigation frequencies, retrieve consumptive use and their interaction

\begin{tabular}{|c|c|c|c|c|c|c|}
\hline \multirow{2}{*}{$\begin{array}{l}\text { Irrigation } \\
\text { Frequencies }\end{array}$} & \multicolumn{3}{|c|}{ Retrieve Consumptive Use } & \multirow[t]{2}{*}{ Mean } & \multicolumn{2}{|c|}{$\overline{\text { LSD for IF }}$} \\
\hline & $(1.00) \mathrm{CU}$ & $\begin{array}{c}(0.70) \\
\mathrm{CU}\end{array}$ & $\begin{array}{c}(0.40) \\
C U\end{array}$ & & 0.05 & 0.01 \\
\hline $\mathbf{I F _ { 1 }}$ & 277.67 & 250.67 & 234.33 & 254.223 & 29.203 & 44.241 \\
\hline $\mathbf{I F}_{2}$ & 240.33 & 214.33 & 202.33 & 218.997 & & \\
\hline $\mathbf{I F}_{3}$ & 219.00 & 194.67 & 183.67 & 199.113 & & \\
\hline $\mathrm{IF}_{4}$ & 196.67 & 182.33 & 162.00 & 180.333 & & \\
\hline Mean & 233.418 & 210.500 & 195.583 & & & \\
\hline \multirow[t]{2}{*}{ LSD for CU } & 0.05 & \multicolumn{2}{|c|}{21.450} & & & \\
\hline & 0.01 & \multicolumn{2}{|c|}{29.554} & & & \\
\hline \multirow[t]{2}{*}{ LSD for IF*CU } & 0.05 & \multicolumn{2}{|c|}{ n.s } & & & \\
\hline & 0.01 & \multicolumn{2}{|l|}{ n.s } & & & \\
\hline
\end{tabular}

The result is similar to previous studies that emphasize the amount of leaf surface area could be increased by increasing irrigation level diman.doski@yahoo.com;
(Khalaf et al., 2019). In another study of Cakir, (2004), who found that reducing soil moisture, leaf area and leaf area index should decrease. akram.khalaf@uod.ac 


\subsubsection{Specific Leaf Area (SLA) $\mathrm{cm}^{2} / \mathrm{g}$}

The statistical analysis shows that there was highly $(\mathrm{p} \leq 0.01)$ significant difference in the plant SLA for different irrigation frequencies, IF, and under different levels of retrieve consumptive use.
The maximum value of SLA was given $46.173 \mathrm{~cm}^{2} / \mathrm{g}$ for IF1, and minimum one 37.553 $\mathrm{cm}^{2} / \mathrm{g}$ for IF4 as related to levels of retrieve $\mathrm{CU}$, the maximum value was $45.825 \mathrm{~cm}^{2} / \mathrm{g}$ under (1.00) $\mathrm{CU}$, and minimum one under was 36.851 $\mathrm{cm}^{2} / \mathrm{g}$ under (0.40) CU retrieve.

Table (8):- Specific Leaf Area affected by Irrigation frequencies, retrieve consumptive use and their interaction.

\begin{tabular}{|c|c|c|c|c|c|c|c|}
\hline \multirow{2}{*}{\multicolumn{2}{|c|}{$\begin{array}{l}\text { Irrigation } \\
\text { Frequencies }\end{array}$}} & \multicolumn{3}{|c|}{ Retrieve Consumptive Use } & \multirow[t]{2}{*}{ Mean } & \multicolumn{2}{|c|}{ LSD for IF } \\
\hline & & $(1.00) \mathrm{CU}$ & $(0.70) \mathrm{CU}$ & $(0.40) \mathrm{CU}$ & & 0.05 & 0.01 \\
\hline $\mathbf{I F}_{1}$ & & 56.504 & 41.512 & 40.504 & 46.173 & 3.813 & 5.776 \\
\hline $\mathrm{IF}_{2}$ & & 46.142 & 36.600 & 36.338 & 39.693 & & \\
\hline $\mathbf{I F}_{3}$ & & 42.155 & 39.867 & 35.606 & 39.209 & & \\
\hline$I_{F_{4}}$ & & 38.497 & 39.206 & 34.955 & 37.553 & & \\
\hline Mean & & 45.825 & 39.296 & 36.851 & & & \\
\hline LSD for CU & 0.05 & & 3.047 & & & & \\
\hline & 0.01 & & 4.198 & & & & \\
\hline LSD for IF*CU & 0.05 & & 6.093 & & & & \\
\hline & 0.01 & & n.s & & & & \\
\hline
\end{tabular}

Also, from same table the interaction effect of irrigation frequencies and retrieve consumptive use on SLA was found only significant under $(\mathrm{p} \leq 0.01)$.

From the findings of limit irrigation studies, it is worthy to mention that in unfavorable environments, plants are forced to regulate the resource allocation of morphological features of the leaf, such as leaf area and leaf thickness, to form an effective SLA pattern through leaf configuration (Thomas, 2010; Wright et al., 2004).

\subsubsection{Plant height (cm)}

There was significant difference $(\mathrm{P} \leq 0.05)$ in plant height among irrigation frequencies, and the maximum sorghum height value was $186.739 \mathrm{~cm}$ and the minimum value of sorghum height was $142.0 \mathrm{~cm}$.

In addition, sorghum height was high significantly affected by retrieve consumptive use $(\mathrm{P} \leq 0.01)$. longest plant height was (172.973) cm (1.00)CU, other retrieve consumptive use which were (157.863 and $150.638 \mathrm{~cm})$ for $(0.70) \mathrm{CU}$ and $(0.40) \mathrm{CU}$. The interaction was highly significant on the same trait. That means, the Sorghum height of all studied retrieve consumptive use was decreased dramatically by reducing these levels.

Table (9) :-Sorghum height in $\mathrm{cm}$ affected by irrigation frequencies, retrieve consumptive use and their interaction.

\begin{tabular}{|c|c|c|c|c|c|c|}
\hline \multirow{2}{*}{$\begin{array}{l}\text { Irrigation } \\
\text { Frequencies }\end{array}$} & \multicolumn{3}{|c|}{ Retrieve Consumptive Use } & \multirow[t]{2}{*}{ Mean } & \multicolumn{2}{|c|}{ LSD for IF } \\
\hline & $(1.00) \mathrm{CU}$ & $(0.70) \mathrm{CU}$ & $\begin{array}{c}(0.40) \\
\mathrm{CU}\end{array}$ & & 0.05 & 0.01 \\
\hline $\mathbf{I F}_{1}$ & 202.55 & 178.78 & 178.89 & 186.739 & 26.034 & n.s \\
\hline $\mathbf{I F}_{2}$ & 185.00 & 144.67 & 135.33 & 155.000 & & \\
\hline $\mathbf{I F}_{3}$ & 149.67 & 166.00 & 159.00 & 158.223 & & \\
\hline $\mathrm{IF}_{4}$ & 154.67 & 142.00 & 129.33 & 142.000 & & \\
\hline Mean & 172.973 & 157.863 & 150.638 & & & \\
\hline \multirow[t]{2}{*}{ LSD for CU } & 0.05 & 11.20 & & & & \\
\hline & 0.01 & $15.44 \mathrm{C}$ & & & & \\
\hline \multirow[t]{2}{*}{ LSD for IF*CU } & 0.05 & 22.411 & & & & \\
\hline & 0.01 & n.s & & & & \\
\hline
\end{tabular}

Plant height can be used as one of the essential measures for assessing water stress in soil. (Sammis et al., 1988) stated that some improvements in the rates of retrieve consumptive use could vary in the plant height. The result showed that Sorghum crop which was irrigated every day was taller $(\mathrm{p}<0.01)$ compared to those which were irrigated every two, three or four days.

The findings of the current research are consistent with other experiments that find taller plants under heavily irrigated water (Ayotamuno 
et al., 1997 and Abdullah et al., 2004), A possible reason for these findings may be that, due to the low supply of water in the root zone, abscisic acid (Saab et al., 1992) and proline (Showler, 2002) accumulation in xylem and water movements, the plant decreased the amount of water loss by transpiration through partial.

\subsection{Crop response factor $(\mathrm{KY})$}

Yield response factor to retrieve consumptive use calculated by applying (Stewart and Dwyer, 1999) model. Average crop response values were $0.765,0.638,0.641,0.845,0.517,0.552$, 0.667 and 0.715 for irrigation frequencies, IF1, IF2, IF3 and IF4 under two range of retrieve consumptive use [(1.00) - (0.70)CU and (1.00) (0.40) CU] (Table 10).

Table (10):- Crop response factor (KY) affected by Irrigation frequencies, Retrieve Consumptive Use.

\begin{tabular}{ccc}
\hline $\begin{array}{c}\text { Irrigation } \\
\text { Frequency }\end{array}$ & \multicolumn{2}{c}{ Average ky } \\
\cline { 2 - 3 } & $\mathbf{( 1 . 0 0 )} \mathbf{C u}-\mathbf{( 0 . 7 0 )}$ & $\mathbf{( 1 . 0 0 )} \mathbf{C u}-(\mathbf{0 . 4 0 )} \mathbf{C u}$ \\
\hline IF1 & 0.765 & 0.517 \\
\hline IF2 & 0.638 & 0.552 \\
\hline IF3 & 0.641 & 0.667 \\
\hline IF4 & 0.845 & 0.715 \\
\hline
\end{tabular}

Values of KY decreased with increasing of irrigation frequencies exceptIF4 for (1.00) -0.70) $\mathrm{CU}$ retrieve whereas inverse trend found for (1.00) - (0.40) CU retrieve.

Also, it can be noticed from above table that average $\mathrm{KY}$ in all conditions for the two ranges $(1.00)$ - $(0.70)$ and $(1.00)-(0.40)$ the KY values were remain less than 1 .

Doorenbos and Kassam (1979) mentioned that , when $\mathrm{KY}<1$, yield loss is less necessary than evapotranspiration stress ; KY $>1$,yield loss is more necessary than evapotranspiration stress and when $\mathrm{KY}=1$, yield loss is equal to evapotranspiration stress.

The results of this study in consistence with findings mentioned as ky values of 0.97 (Yildrin et al., 1996) , 0.98 (Kanber et al., 1990) were reported for whole growing season. While (Karam et al., 2003) indicated that KY values of 0.81 for drip irrigated maize for the entire growing season.

\section{CONCLUSIONS:}

According to the present study the following points were found:

1. The growth parameters of Sorghum crop speed feed variety increased with increasing irrigation frequency, and the maximum values of Sorghum growth parameters were obtained for IF1 under (1.00 CU) retrieve.

2. The best combination between irrigation frequency and retrieve consumptive use was obtained for irrigation frequency; IF1 (Once in 1 day) and $(1.00 \mathrm{CU})$ retrieve consumptive use.
3. The retrieve consumptive use gave a highly significant increase in all parameters of growth.

4. The same amounts of applied irrigation water under the same levels of retrieve consumptive use for four different irrigation frequencies IF1, IF2, IF3 and IF4 were found.

\section{RECOMMENDATIONS:}

From the results of the present research the following points are recommended:

1. The irrigation frequencies IF1, (Once in1day) and IF2 (Once in 2days), under level (1.00 CU) retrieve are recommended to cultivate Sorghum crop (speed feed variety) for Duhok semi-arid conditions.

2. More investigation is needed to study to determine the effect of space between Sorghum (speed feed) crop plants and under different conditions climate and weather effects.

3. Rely on crop response factor (KY) and $\mathrm{ET}_{\mathrm{a}} / \mathrm{ET}_{\mathrm{m}}$ under retrieve consumptive use irrigation condition.

4. Further research is needed to study the effect of different levels of irrigation frequency with different sources or water qualities.

\section{REFERENCE}

Abdelmula, A.A. and Sabiel, S.A.I., 2007, October. Genotypic and differential responses of growth and yield of some maize (Zea mays L.) genotypes to drought stress. In Proceedings of the Tropical (Tropntag 2007) German Conference (Utilization of diversity in land (pp. 9-11).

Abdullah, K., Gokhan, T., Yusuf, U. and Belgin, C., 2004. Effects of mulch and irrigation water akram.khalaf@uod.ac 
amounts on lettuce's yield, evapotranspiration, transpiration and soil evaporation in Isparta location, Turkey. Journal of Biological Science, 4, pp.751-755.

Addo-Quaye, A.A., A.A. Darkawa, and G.K. Ocloo., 2011. Growth analysis of component in a maize-soybean intercropping system as affected by time of croping and spatial arrangement. ARPN Journal of Agricultural and Biological Science 6(6):34-44.

Allen, R.G., Pereira, L.S., Raes, D. and Smith, M., 1998. Crop evapotranspiration-Guidelines for computing crop water requirements-FAO Irrigation and drainage paper 56. FAO, Rome, 300(9), ppD05109.

Al-Mozani, S. J. and K. I. Al- Tai., 2014. The effect of genotypes and stage of cutting in the quantity and the quality of sorghum forage. The Iraqi. J. Agric. Sci. 45. (6): 537546.

Al-Sulaivani, S.I.A. 1993. Physicochemical Behavior of Ortho and Pyrophosphate in Some Calcareous Soils from Northern of Iraq (Doctoral dissertation, Ph. D.Dissertation, University of Baghdad). ASAE 323-334.

Assouline, S. 2002. The effects of micro drip and conventional drip irrigation on water distribution and uptake. Soil Sci. Soc. Am. J.66, 1630-1636.

Attiya, H. J. and K. M. Whib., 1989. Understanding of crop production. Translated, printed in ALHikma publication, Univ. of Baghdad.

Ayotamuno, J.M., Akor, A.J., Teme, S.C., Essiet, E.W.U., Isirimah, N.O. and Idike, F.I., 1997. Computing maize crop coefficients in the Port Harcourt area, Nigeria, using a class A pan evaporimeter. Outlook on agriculture,26(3), pp.185-189.

Bashour, I.I. and Sayegh, A.H., 2007. Methods of analysis for soils of arid and semi-arid regions. FAO.

Cakir, R. 2004. Effect of water stress at different development stages on vegetative and reproductive growth of corn. Field Crops Research, 89(1), 1-16.

Doorenbos, J. and Kassam, A.H., 1979. Yield response to water. FAO Irrigation and drainage paper, No. 33, FAO, Roma, Italia. p.257.

El-Hendawy, S.E., Abd El-Lattief, E.A., Ahmed, A.S. and Schmidhalter, U., 2008a. Irrigation rate and plant density effects on yield and water use efficiency of drip-irrigated corn. Agric. Water Manage. 95, 836-844.

El-Hendawy, S.E., Hokam, E.M. and Schmidhalter, U., 2008b. Drip irrigation frequency: the effects and their interaction with nitrogen fertilization on sandy soil water distribution, maize yield and water use efficiency under Egyptian conditions. J. Agron. Crop Sci. 194, 180-192.

Enyi, B.A.C. 1977. Analysis growth and yield of two diman.doski@yahoo.com; sorghum varieties. Ghana Jnl agric. Sci. 10:165-176.

Estefan, G., Sommer, R. and Ryan, J., 2013. Methods of soil, plant, and water analysis: A manual for the west, Asia and North Africa Region. ICARDA, Beirut, Lebanon.

Farahani, H.J., Izzi, G. and Oweis, T.Y., 2009. Parameterization and evaluation of the Aqua Crop model for full and deficit irrigated cotton. Agronomy Journal, 101(3), pp.469-476.

Fattah, M.A. 2009. The interactive effects of water magnetic treatment and deficit irrigation on plant productivity and water use efficiency of corn (Zea mays L.). MSc theses. University of Sulaimani. Sulaimani-Iraq.

Fghire, R., Anaya, F., Issa, O. A., \& Wahbi, S. (2017). Physiological and growth response traits to water deficit as indicators of tolerance criteria between quinoa genotypes. Journal of Materials and Environmental Sciences, 8(6), 2084-2093.

Gardner, F.P., R.B. Pearce, and R.L. Mitchell., 1991. Fisiologi tanaman budidaya. Cetakan pertama. Judul asli: Physiology of crop crops. Penerjemah: H. Susilo. Pendamping: Subiyanto. UI-Press. Jakarta.

Hancoch, D. W., U. Saha., R. L. Stewart., J. K. Bernard., R. C. Smith, and J. M. Johnson., 2014. Understanding and improving forage quality.USA Extension Bulletin 1425.

Heerman, D.F. 1985. ET in irrigation management. In proceedings of the National Conference on Advances in Evapotranspiration. Trans. ASAE 323-334

Hsiao, T.C., Heng, L., Steduto, P., Rojas-Lara, B., Raes, D. and Fereres, E., 2009. AquaCrop-the FAO Crop Model to simulate yield response to water: III. Parameterization and testing for maize. Agronomy Journal, 101(3), pp.448-459.

Israelson, D.W., and V.E. Hansen, 1980. Irrigation principles and practices $4^{\text {th }}$ ed., Wiley, New York.

Jamieson, P.D., Martin, R.J., Francis, G.S. and Wilson, D.R., 1995. Drought effects on biomass production and radiation use efficiency in barley. Field Crops Res., 43, 7786.

Kanber, R., Yazar, A. and Eylen, M., 1990. Wateryield relations of second crop corn grown after wheat under Cukurova conditions. Research Institute of Tarsus. General Publication 156p.

Karam, F., Breidy, J., Stephan, C. and Rouphael, J., 2003. Evapotranspiration, yield and water use efficiency of drip irrigated corn in the Bekaa Valley of Lebanon. Agricultural Water Management, 63(2), pp.125-137.

Khalaf, A. A., Issazadeh, L., Abdullah, Z. A., and Hassanpour, J., 2019. Growth and Yield Assessment of Two Types of Sorghum-Sudan grass Hybrids as Affected by Deficit Irrigation

akram.khalaf@uod.ac 
International Journal of Agricultural and Biosystems. Engineering, 13(7), 214-218.

Klute, A.(ed), 1986. Methods of soil analysis. Part $1.2^{\text {nd }}$ ed. Agron. Monogr. 9.ASA and SSSA. Madison. WI.

Moore, K. T. and H. J. G. Jung., 2001. Lignin and fiber digestion. J. R. Man.54: 420430.

Musick, J.T., and Dusek, D.A., 1980. Irrigation corn response to water transaction of the American Society of Agricultural Engineers 23(1):92-98, 103.

Ottman, M. J. and M. W. Olsen., 2009. Growing grain sorghum in Arizona. The university of Arizona, college of Agriculture and life Sciences; Arizona 85721.

Pandey, R.K., Maranville, J.W. and Admou, A., 2000. Deficit irrigation and nitrogen effects on maize in a Sahelian environment. I. Grain yield and yield components. Agric. Water Manage. $46,1-13$.

Payero, J.O., Tarkalson, D.D., Irmak, S., Davison, D. and Petersen, J.L., 2008. Effect of irrigation amounts applied with subsurface drip irrigation on corn evapotranspiration, yield, water use efficiency, and dry matter production in a semiarid climate. Agricultural Water Management, 95(8), pp.895-908.

Prakash, R., K. Ramamurthy., A. Nirmala Kumari, and P. Nagarjan., 2010. Correlation and path analysis in sorghum. Electronic Jour. of plant Breeding.1(3):315-318.

Pollo, R., Sitompul, S. M., Guritno, B. and Tyasmoro, Y. S., 2018. CROP GROWTH PARAMETERS OF GRAIN SORGHUM VARIETIES (SORGHUM BICOLOR (L.) MOENCH) AT DIFFERENT CROP SPACING. Russian Journal of Agricultural and Socio-Economic Sciences, 74(2).

Ramazanzadeh, S. and M.R. Asgharipour., 2011. Physiological growth responses of sorghum genotypes to impairment of crop photosynthesis using potassium iodide. Australian Journal of Basic and Applied Sciences 5(11):1884-1890.

Rowell, D.L. 2014. Soil science: Methods \& applications. Routledge.

Saab, I.N., Sharp, R.E. and Pritchard, J., 1992. Effect of inhibition of abscisic acid accumulation on the spatial distribution of elongation in the primary root and mesocotyl of maize at low water potentials. Plant Physiology, 99(1), pp.26-33.

Saberi, A. R., and Aishah, S. H., 2013. Growth analysis of forage sorghum (Sorghum bicolor L.) varieties under varying salinity and irrigation frequency. International Journal of Biotechnology, 2(7), 130-140.

Sammis, T.W., Smeal, D. and Williams, S., 1988. Predicting corn yield under limited irrigation using plant height. Transactions of the ASAE, 31(3), pp.830-0837.

Showler, A.T. 2002. Effects of water deficit stress, shade, weed competition, and kaolin particle film on selected foliar free amino acid accumulations in cotton, Gossypium hirsutum (L.). Journal of Chemical Ecology, 28(3), pp.631-651.

Stewart, D.W. and Dwyer, L.M., 1999. Mathematical characterization of leaf shape and area of maize hybrids. Crop Science, 39(2), pp.422- 427.

Stone, P.J., Wilson, D.R., Jamieson, P.D. and Gillespie, R.N., 2001. Water deficit effects on sweet corn. Part II. Canopy development. Aust. J. Agric. Res., 52, 115-126.

Thomas, S.C. 2010. Photosynthetic capacity peaks at intermediate size in temperate deciduous trees. Tree Physiol. 30, 555. https: //doi. org/10.1093/treephys/tpq005

Walkely, A. and Black, I.A., 1934. An examination of the Degtjareff method for determining soil organic matter, and a proposed modification of the chromic acid titration method. Soil science, 37(1), pp.29-38.

Wang, F.X., Kang, Y. and Liu, S.P., 2006. Effects of drip irrigation frequency on soil wetting pattern and potato growth in North China Plain. Agric. Water Manage.79,248-264.

Wright, I.J., Reich, P.B., Westoby, M., Ackerly, D.D., Baruch, Z., Bongers, F., CavenderBares, J., Chapin, T., Cornelissen, J.H. and Diemer, M., 2004. The worldwide leaf economics spectrum. Nature 428, 821. https://doi.org/10.1038/nature02403

Yihun, Y.M., Schultz, B., Mehari Haile, A. and Erkossa, T., 2011. Optimizing Teff productivity in water stressed region of Ethiopia. ICID 21st International Congress on Irrigation and Drainage.

Yildirin, O., Kodal, S., Selenay, F., Yildirin, Y.E. and Ozturk, A., 1996. Yeterli ve kistil sulma suyu Kosullarianda Misir Verimi. Turk. J. Agric. For. 20 (4):283-288 (English abstract). 